Article

\title{
Decision Making Based on Benefit-Costs Analysis: Costs of Preventive Retrofit versus Costs of Repair after Earthquake Hazards
}

\author{
Maria Bostenaru Dan ${ }^{(1)}$ \\ Department of Urban and Landscape Design, "Ion Mincu” University of Architecture and Urbanism, \\ 010014 Bucharest, Romania; Maria.Bostenaru-Dan@alumni.uni-karlsruhe.de; Tel.: +40-771-225-139
}

Received: 31 March 2018; Accepted: 9 May 2018; Published: 11 May 2018

\begin{abstract}
The reduction of seismic risk through the retrofitting of historic buildings serves catastrophe management. In the application of such measures, actors from the spheres of the passive public, experts, as well as active affected people, are involved. The focus of this work is on planning management in the expert area, with a detailed view on the decision space between goals, means, benefits and costs. Buildings of a typology were modelled, and the models translated using a finite elements software with fibre-based modelling of plasticity. The concept of retrofit elements was developed, in order to connect building surveys, construction management, structural simulations, and costs computation based on devices, all related to these retrofit elements. With a view to the general methodology, in order to compare the costs for repairs to buildings after an earthquake with the costs associated with preventive retrofitting of an undamaged building, several cases were considered: damages on a non-retrofitted building, damages on retrofitted building, retrofitting on an undamaged building, retrofitting on a pre-damaged building, and the subsequent damages in an earthquake for the last two. The innovative part of this research lies in the use of the tension-elongation approach to models of building size. Such an analysis allows not only the description of ways of collapsing and the setting of limit states, but also exactly the specific amount and position of the structural members which fail in certain performance criteria. This type of results can form the basis for interdisciplinary studies, such as economic efficiency studies. The method was applied for early reinforced concrete buildings, which are common in Bucharest, Romania, in a deterministic method which takes into account recorded earthquakes. In conclusion, depending on the size of an earthquake, the timing and extent of the retrofit to be applied differ, if we are to obtain cost savings in preventive retrofitting compared to post-earthquake repair. This is presented through a range of costs curves.
\end{abstract}

Keywords: economic efficiency; multi-criteria decision; heritage buildings; earthquake; retrofit

\section{Introduction}

This paper addresses decision-making foundations of pre-earthquake retrofitting versus post-earthquake repair of pre-code, reinforced concrete skeleton buildings. Retrofit measures have an impact on the appearance of heritage buildings. This is why a number of actors are involved in a benefit-costs analysis.

Research in economic efficiency has been scarce. Notable studies are FEMA [1], which includes a database on seismic retrofit measures, and research from other countries, such as Germany, which have related databases on interventions on existing buildings [2]. In Romania, INCERC [3] has published seismic retrofit devices such as those employed in this research. Despite their scarcity, such studies are of great importance, since the relationship between benefit and cost of a retrofit measure may influence 
the application of such a measure in earthquake prone areas, and through their application, save lives in future earthquakes, as well as protecting cultural heritage from irreversible damage through the appropriate choice of an adequate seismic retrofit system and strategy. In the case where this study is exemplified, despite being classified as risk category I, only a few buildings are retrofitted, given the trauma associated with demolitions undertaken in the former totalitarian time. Hence, leaving the flat during retrofitting work is not an option, as inhabitants, who are in this case also owners in condominiums in the central area of Bucharest where most such buildings are located, are afraid that they will be unable to return. Retrofitting measures and strategies considering only the facade were chosen for this study, as this can be compared to energy retrofitting, which has a high level of acceptance in the city, and is being widely performed.

At the same time, most seismic risk I category buildings are located in an area situated in the protection zone "Magheru Modernist Boulevard". Former studies on the area, such as those in the projects RISK-UE and Sonderforschungsbereich 461, considered these buildings, which are either monuments or part of Romania's architectural heritage, as common buildings. The measures proposed take into account the inclination of the architect to minimally intervene, in order to not alter a given building's authentic substance.

In this work, we aim to develop economic efficiency curves, which, in relationship to performance curves, may establish how much damage may be taken into account, depending on the size and recurrence rate of the earthquakes. The collapse of the building was not a considered outcome. INCERC [4] has published three-dimensional curves based on the existing databases, but our study aims to make them conceptual, i.e., independent of databases. ATC-40 [5] contains documentation on cost studies as well, albeit without building a family of curves as we envisage to do.

In Europe, costs studies of earthquake retrofitting have been performed by Smyth et al. [6] for Turkey and Lekidis et al. [7], as well as Kappos and Dimitrakopoulos [8] for Thessaloniki, Greece. The latter builds on Kappos et al. [9], and both envisage reinforced concrete buildings, as does our study. Following the 1999 Athens earthquake, the studies have been updated [7,10]. However, like the studies mentioned above, they rely on the existence of databases, something that we have tried to overcome, through the use of formulas, in our study.

Extant Romanian earthquake retrofit studies include Zikas and Gehbauer [11] and Zikas et al. [12], as well as our previous studies [13-17]. These show progressively how, on the basis of structural mechanics based computations, cost analyses can be performed site independently, replacing the values of costs specific to the respective tables. The benefit analysis requires a multi-criteria decision, such as the one presented here. In this regard, in an international context, related research has been performed by Caterino et al. [18,19]. Bostenaru and Bourlotos [20] attempted a transition of stone masonry buildings, albeit without the structural mechanics basis of reinforced concrete.

Other loss estimation approaches refer rather to large scales. Assessing economic efficiency can be done for individual buildings and classes of buildings. According to recent methods [21-24], it is possible to switch from a single building of a certain class by simplifying the probabilistic method, as median inaccuracies resulting from simplification are rectified. Instead of considering statistics, the mechanical characteristics of the buildings are considered, and computations are based thereon. Here, we have made reference only to studies concerning reinforced concrete buildings, which are our subject; nonetheless, similar studies have been done for masonry buildings.

In our paper, a method was developed for individual buildings. To make the transition to a building class, costs were calculated for several example buildings for earthquakes of different intensities. Through this comparison, objects were created that could be used to design the various means of achieving economic efficiency. In addition to the structural performance of the building, there are many other factors that may be used to measure benefits, such as:

- Cost of repair to replacement cost,

- Existing retrofit technologies,

- Relocation need of the residents, 
- Duration of the measure,

- Functional or aesthetic restrictions,

- $\quad$ The historical significance of the structural materials.

The guidelines for the seismic strengthening of historical buildings were reviewed in building the decision tree: the Venice Charter (1964), ICOMOS and European recommendations, incorporated into studies about risk threats [25], or the Eurocode 8. While these are approaches for heritage buildings, for common buildings, performance levels are primarily what is to be considered in decision making. The Venice Charter, for example, was concerned about the construction materials, and, while it is not recommended that the masonry techniques employed in the buildings which are the subject of this research be used today, being solid brick, the concrete is not of lower strength. Regarding ICOMOS, apart from the heritage of the risk report of [25], we reviewed the ISCARSAH recommendations from Assisi (http:/ /iscarsah.icomos.org/index.php?option=com_content\&view=article\&id=59\&Itemid=71) in the aftermath of the 1997 Umbria-Marche earthquake. One of the elements of the declaration focuses on the importance of preventive measures, as was later referenced in the preventive conservation conference in Como (see [17]).

The ability to create high quality living spaces depends upon the benefits of measures of increased security; building measures were investigated with regard to factors of cost, structural performance, and architectural possibilities of participation. Another aspect is the ordering of priorities. A model has been chosen for balancing the solution with the problem, through multi-criteria based decisions.

For such decisions, we drew upon Malczewski's book [26] regarding spatial problems. The architect Richter (course work) was made a role model in decision-making between goals, resources, benefits and costs. In restorations, the model used in Weissenhof, the Modernist Werkbund Siedlung in Stuttgart, Germany, was described by Nägele [27]. The ATC-40 considers a series of actors specifically for seismic retrofitting. Both latter models employ matrixes (decision tables). At the urban planning level, Fingerhuth and Koch [28] clarified the moderating role of the architect, among experts, passive public, and other active, affected people. The role of users was also considered by Ottokar Uhl in the model developed for the Hollabrunn in the 1970s, the golden-age of participative planning. At a regional planning level, Strassert [29] developed a method of balancing which will be employed later. Nägele [27] also employed balancing.

\section{Experimental Section}

\subsection{The RC Skeleton among Typologies in Bucharest, Romania Performance Levels and Seismic Retrofit Costs}

For this paper, we considered the building typology of interwar reinforced concrete skeletons, also called (by us) 'early reinforced concrete' (1920-1940). The typology was investigated through field studies for both the exterior and the interior of the buildings, as well as through studies of the archives, both physically and online, and of newspapers from the time when the projects were first published, physically and online, through using archives of the building permits from the city hall. Most books do not contain building plans, which are useful for the focus of this research, whose accent remains on the facade. However, for the economic computations in this paper, we needed the plans of buildings to compute the costs, according to architectural methods. These architectural methods use the mean value of certain physical surfaces to compute the costs for a new building by using mean values from similar, so-called "comparison objects".

In framework of the "World Housing Encyclopedia" [WHE] project [30], Romanian housing typologies in Bucharest were analysed. The typologies, which cover all historical time spans preserved in the city, are:

- $\quad$ Historic building with timbered balconies (1850-1880),

- " "Wagon" house (single story brick row) (1880-1920, WHE report \# 85),

- Two story brick masonry timber floor (for New Romanian, around 1920, WHE report \# 84), 
- Multistory brick masonry steel composite floor (for New Romanian),

- Reinforced concrete (RC) skeleton (residential-WHE report \# 96-and mixed use) (1920-1940),

- $\quad$ RC skeleton with RC braces (post-war and pre-nationalisation typology, WHE report \#71) (1940-1950),

- $\quad$ Cast in situ RC structural walls (vulnerable-WHE report \# 78-and not-WHE report \# 87) (1950-1977),

- $\quad$ Precast RC structural walls (1977-1989, WHE report \# 83),

- $\quad$ Moment resisting RC frame multi-storey (socialist WHE report \#97, 1977-1989),

- $\quad$ Moment resisting RC frame low rise (post 1989).

RC skeleton structures from the interwar time (Figure 1) proved to be the most vulnerable.

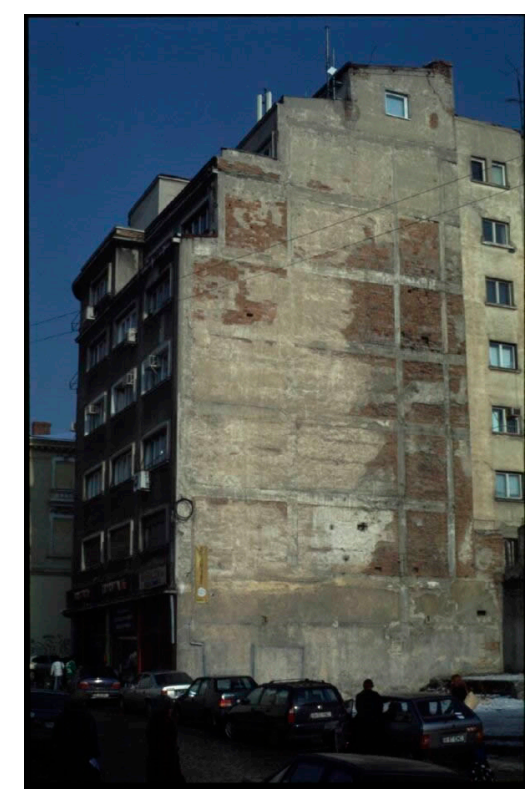

(a)

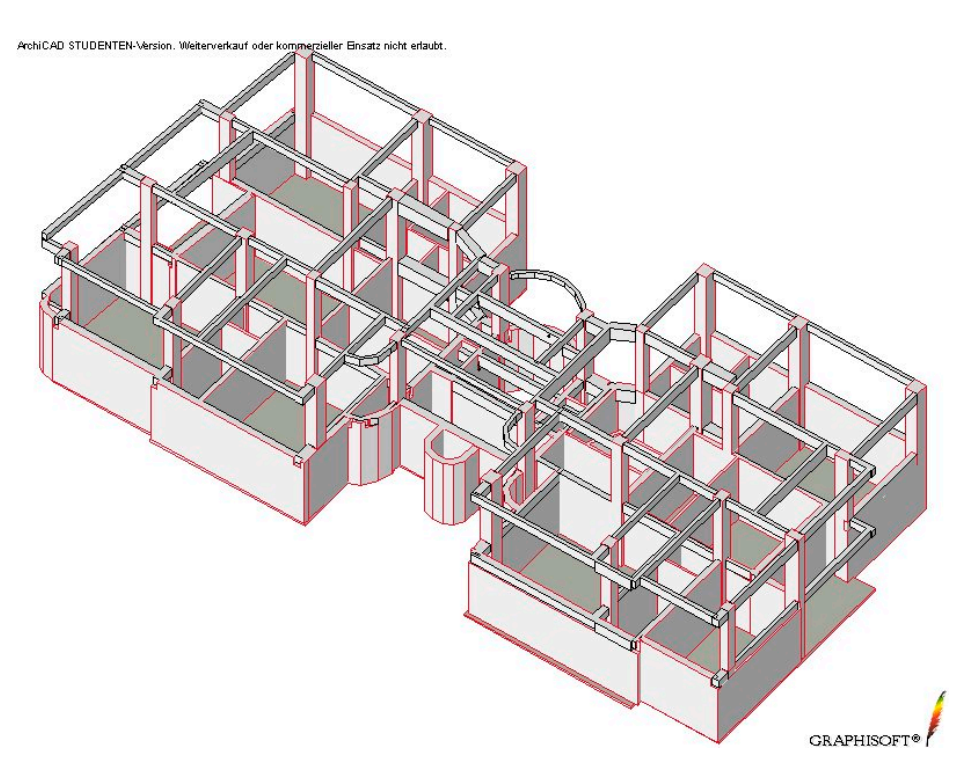

(b)

Figure 1. Typical reinforced concrete building from interwar time in Romania. (a) View, (b) axonometric view.

For setting priorities at the urban scale, two approaches can be adopted. The selection by area involves the application of a scenario in a heterogeneous area containing closed heterogeneous blocks. The selection follows goal elements, in this case, classes of buildings, and is based on the scenario of the punctual application for buildings which are unevenly distributed throughout the area.

This was also employed in the questionnaire (Table 1) for the SFB 461 (Sonderforschungsbereich 461, which was a German Collaborative Research Centre running from 1996 to 2007, with the topic "Vrancea earthquakes. From geosciences to engineering measures." at the then University of Karlsruhe), for surveying the central area of Bucharest. The typologies surveyed for the WHE correspond to the same time spans. The following is the questionnaire that was developed by the author, in the framework of SFB 461, in order to survey the building materials used in a central protected area of Bucharest.

The WHE has a component called PAGES to estimate loss in different countries; however, we could not contribute to that part, due to lack of data. Completion was accomplished by another team. 
Table 1. The questionnaire employed for the survey.

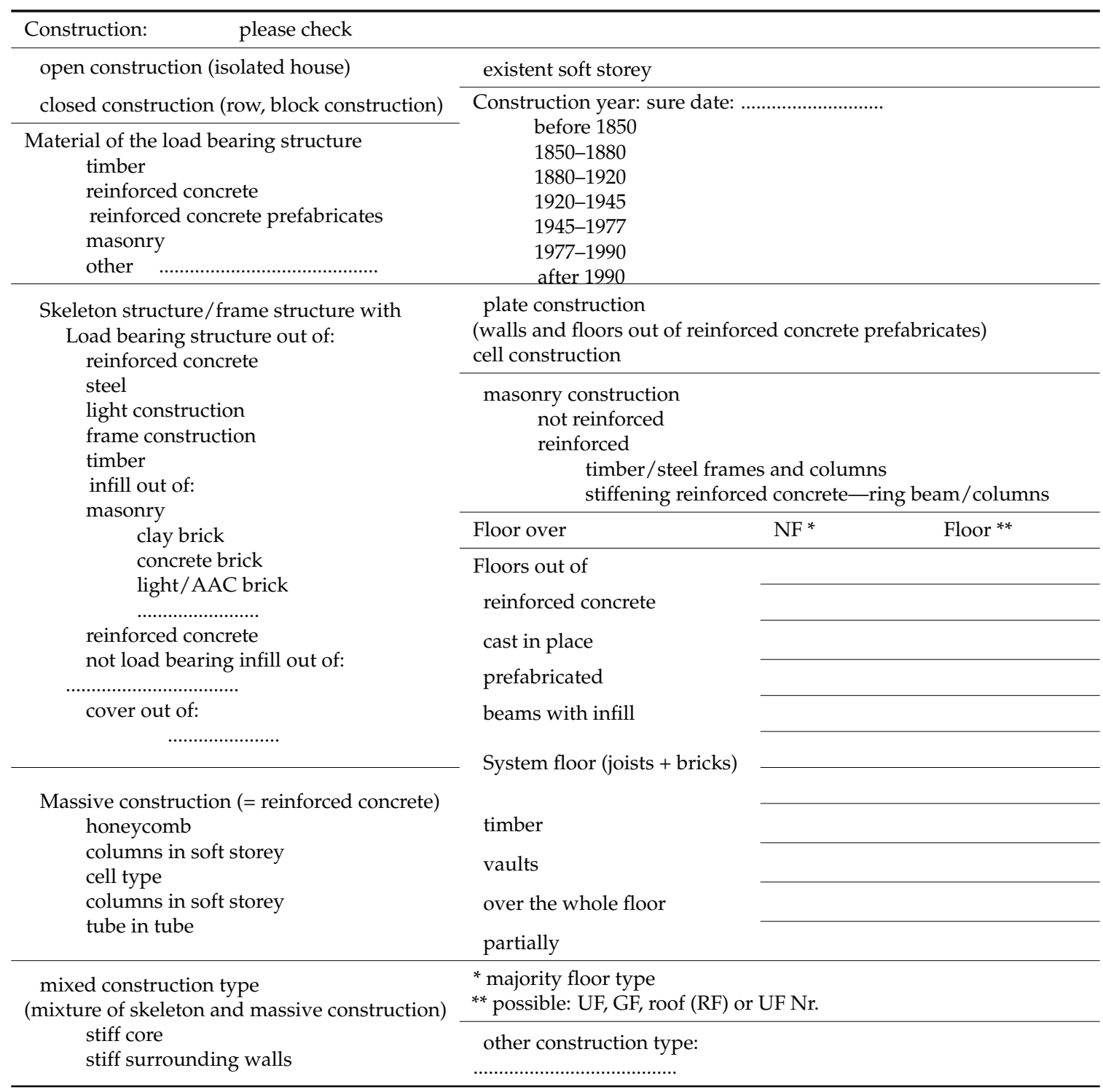

\subsection{Performance Levels and Seismic Retrofit Costs}

The inspiration for the concept of developing retrofit costs curves comes from studies in the theory of daylight in atria. In such atria, in order to acquire sufficient daylight as deeply as possible within the building, a different kind of recess was introduced. There is a second window, whose role is to bring light further inside. Translated to earthquake costs curves, this means that, depending on the expected earthquake, the measure can be more, or less, extensive (Figure 2). Adding a second window should be similar to adding a retrofit element. The curve for daylight is therefore mirrored vertically to obtain an idealised cost-curve. A scheme by Paulay was used to compare the model, but the implementation of the cost-curves concept suffers through limitations associated with assumptions made in structural modelling, i.e., the ideal curve differs from the computed one (Figure 2c). Improvements to this are expected in future studies.

Diagrams have been created to see how the total costs of preventive retrofitting and post-earthquake repair vary; tables present comparisons to the costs of rebuilding. At the moment when a repair measure has to be applied, the function of the recurrence period of earthquakes is similar to the depth of the atria. Depending on how strong the expected earthquake is, a more extensive retrofit is required, in order to decrease repair costs. 

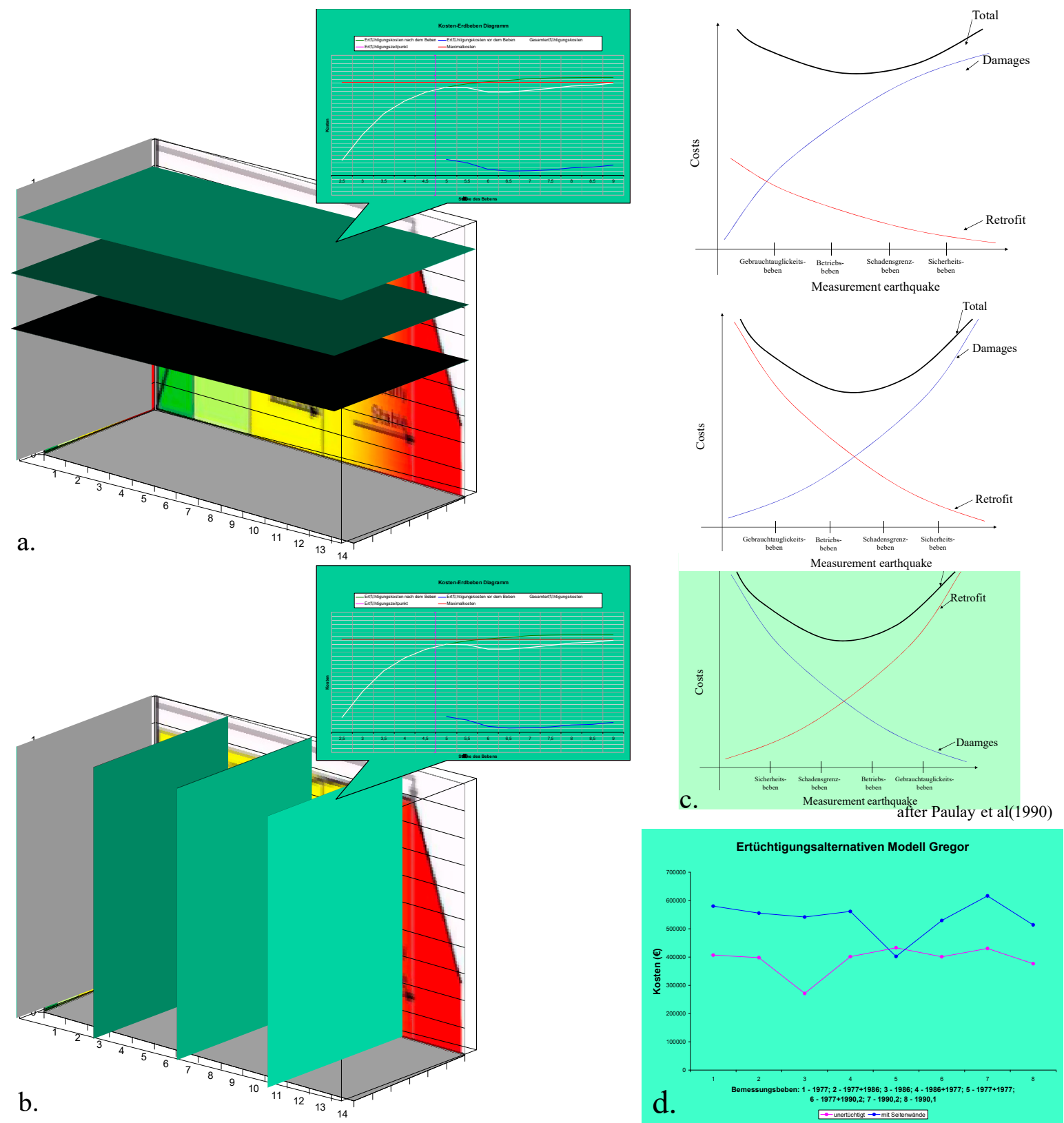

Figure 2. The development of the costs curves concept. (a,b) The concept of a family of curves, (c) basis in literature, (d) results of computations for one of the models considered.

For Figure $2 \mathrm{~b}$, the idea was to create a family of curves of costs, depending on the amount of retrofitting required, in order to meet a specific performance level. As we noted in the introduction, there are few works creating such families of curves; one is the work of Paulay. In this writing, the costs of retrofitting increase when the magnitude of the earthquake for which the respective performance has to be achieved decreases. At the same time, the costs for damage reparation decrease as well, as the building will be less damaged at lower magnitude earthquakes. For an earthquake which leaves little damage, the costs for retrofitting might be higher than those for repairing small levels of damage; however, this is inversed in case of an earthquake which leaves high damage and for which a modest investment in retrofitting would have prevented high levels of damage. We inversed the scale in order to fit our costs curves. We started at the earthquake for which the operations of the building as a whole have to be assured, followed by the earthquake where damage is limited, and finally by the 
earthquake for which collapse must be avoided. Finally, we note in the concept that while the curves of Paulay are logarithmic in shape, we propose an alternative. The retrofitting costs vary inverse logarithmically on our scale, but start at a lower value; however, for damage, the shape of the curve is the inverse, and maintains the same extremes. As a second step we generated the family of curves in a 3D graph. On the $X$ direction, we got the size of the earthquake, i.e., the performance level which has to be achieved. For frequent earthquakes, as already noted, we have to reach total functionality, while for rare, strong earthquakes, collapse prevention is the goal. On the $Z$ axis for this side of the graph, we have damage. On the $Y$ axis, we have the costs of retrofitting as the curve generated by the additional window, which may be closer to, or further from, the main window, depending on depth. For each of the three considered earthquakes, we have a different curve. Now we will discuss the adaptation from the aforementioned light design. We consider the costs for damage (the $Z$ axis) as the curve generated by the main window, and the costs of retrofitting as the curve generated by the additional window, which may be closer to, or further from, the main window, depending on the depth, which is represented here on the $X$ axis, the time of recurrence of the earthquakes which determines the targeted performance level. The total cost has a shape which increases and decreases, and the target of the intervention should not exceed a total within the highest point of the curve.

For Figure 2a, the derivation from daylight shall be understood as follows: let's imagine a building consisting of parallel bars. In this case, the light comes through the courtyard, and is decreased in the lower levels by shadows. To overcome this, a building with stepwise recesses in the height has been designed. Thus the courtyard in the ground floor has the smallest dimensions, and increases in width with height. Therefore, the level of shadow decreases with height, and more natural light is received by the higher floors. However, for deep rooms, even this natural light is not enough. To deal with the depth, a second window was added, following the line of the next floor, which is set back in the building. To optimize the light design, the amount of setting back depends on the floor. The second window is closer to the main one in the lower floor, and further in the upper floors, where the natural light amount decreases. Transferred into our concept, the window symbolizes the amount of the measure; by 'amount' we understand the costs associated with a certain retrofit or repair intervention. The main window stays for repair, and the additional one for retrofitting. The lower the floor is, the less effect the investment in repair has, because the damages are more extensive. The deeper floors correspond to stronger earthquakes, i.e., a less favourable situation. The "moment of the measure" remains for the earthquake we consider to set our measure, targeted with, in German called "Bemessungsbeben", and with which we can consider that the building shall be designed in order to reach a certain performance level. The moment of the measure, although remaining on the $X$ axis, is actually determined by the $Y$ axis value, i.e., the curve is be drawn for a lower or an upper story, which are the ones determined parametrically by earthquake magnitude.

In our study, we considered two different categories of earthquakes: the 1977 earthquake, which caused significant damage, and the rather moderate earthquakes of 1986 and 1990 (as well as some of them combined). As we did not have accelerograms for all categories, we could not generate the curve from this concept.

We are not counting for collapse, but rather, for damage, comparing repair and retrofitting in these costs curves. Rebuilding will be considered in the tables explained subsequently.

\subsection{Building Modelling}

Based on typology study, two model buildings were designed; for one of these, different retrofit measures (side walls, structural walls, steel braces, steel jacketing, measures described in Dritsos [31]) were considered, while for the other, retrofit measures (diagonal braces, which permits adding active measures such, as energy dissipaters) to different extents and locations in the building were considered. As such, different retrofit strategies were considered. The first model, called "Gregor", is a regular structure, $22 \mathrm{~m}$ high, $20 \mathrm{~m}$ long and $15 \mathrm{~m}$ wide. It has six storeys, four spans in one direction, and three in the opposite direction. The frames are identical in both directions, $3 \mathrm{~m}$ high and with a $4.5 \mathrm{~m}$ span, 
with $50 \mathrm{~cm}$ wide square columns. The beams are also $50 \mathrm{~cm}$ high. The reinforcement was designed, as described in the WHE, for interwar buildings. The first measure is the addition of side walls to the right and the left of the columns, in the middle along the wall of the building. In the case of steel jacketing, which can be easily modelled using the software SeismoStruct, through considering a different confinement, the advantage is that the section of the retrofit element does not increase. Structural walls can also be completely added to the frame to increase rigidity, in case of an earthquake. Diagonal braces were also inspired by a rare form that was used in the interwar time in Bucharest, whose typology, with reinforced concrete diagonal braces, performed better in earthquakes. The model "Özzi", which has the same characteristics as "Gregor" (except that it is more symmetrical), builds on different strategies, according to [5], for the same measure of diagonal steel brace retrofitting. The possibilities for the later development of such a retrofit will be discussed. For the smaller span, a lower span of $3.5 \mathrm{~m}$ was considered, which is frequent in Romanian building typologies. We observed that in both cases, the retrofit was performed on the facade elements, thus minimising intervention in the interior of the building. For the building proper (Figure $1 \mathrm{~b}$ as compared to the thumb in Table 5) such measures were also performed on the façade; hence, the proposal is close to reality. The chosen seismic retrofitting measures are traditional, and have been proven in many earthquakes to be different to, for example, FRP retrofitting, which has the advantage of more reversibility; this has been the subject of another study [32].

It was our intention to model a typical interwar reinforced concrete building for our structural studies. The study of the structural typology of early reinforced concrete buildings in the former chapter was done for this reason. For this, we considered the report of building typology for the WHE (extended characteristics), and we performed a study of plan layout in order to identify the typologies of the distribution of spans and bays in skeleton buildings in existing interwar buildings in Romania, in order to see how much the proposed model is similar to what can be found on site. In real Romanian buildings, there are often secondary beams supported by one end of a column, and by the other on a beam, which causes a high irregularity in reactions to earthquakes.

The conceptual model served in the modelling software for the building. Retrofit measures have also been modelled using a fibre-based software (SeismoStruct), with advantages explained later. For some of the measures, special sections existed, permitting the step between two successively applied earthquakes, while for others, these had to be developed. We defined herewith the retrofit elements, which can be new elements (added), old elements, to which something has been added (ex. jacketing), repaired elements, or downgraded elements (from load bearing to not load bearing). The structural morphology that is changed through this, and through this kind of optimization, is the subject of another study.

\subsection{Computation Methodology}

Device computations, a civil engineering method for building economics (and one which was, before statistics existed, also the method for computing the costs of general upgrades to buildings), were done for the retrofitting and repair measures, being able to be applied for different countries, also those where there is no database on existing projects vis a vis seismic retrofitting. The building elements for which the device computations were done are named "retrofit elements", and they can be new elements, modified elements, or replaced elements in the initial building. For example, jacketing can be done on the undamaged element before the earthquake, on the damaged element after an earthquake, and before the second earthquake (as an option for this eventuality exists in the software). The retrofit elements can easily be converted into cost-computation devices.

The addition of the devices is simple, as the row in project management was, but for the sake of comparison, also complex. Project management computed in other works was compared for innovative measures, such as FRP (with glass and fibre) [32].

Two different computation methodologies for costs were applied: one, coming from construction management as understood by engineers, as used by the architects according to the German HOAI 
(Honorarordnung für Architekten und Ingenieure-the regulation for payment of architects and engineers) rules; the latter, as stated for the costs of rebuilt. Calculations using surfaces from architects' HOAI were employed for rebuilding in case of total damage. For this, MS Excel forms developed by Bogenstätter (University of Karlsruhe) were employed. There is now an option for use of new BIM (Building Information Models) software (ex. ArchiCAD since the 2011 version) in interventions on existing buildings.

Calculation using construction devices, derived from the project (construction) management methods of the civil engineers, was done with the "retrofit elements", which were developed for computing the costs of retrofitting.

\section{Retrofit measures}

- $\quad$ Repair measures after earthquake damage, depending on the extent of the damage (the software SeismoStruct allowed us to apply the retrofit method to a pre-damaged element)

The following formulas cost devices were applied:

- Reparation

$$
\begin{aligned}
& \text { Reparation of a column with fracture }=48.16 \times \sigma \lambda+1 \times \varepsilon \beta+270 \times \sigma \tau+10 \times \sigma \eta+ \\
& 25 \times \sigma \eta v+1 \times \beta \\
& \text { Reparation of a beam with fracture }=41.68 \times \sigma \lambda+1 \times \varepsilon \beta+2 \times \delta+270 \times \sigma \tau+0.9 \times \\
& \sigma \eta+2.4 \times \sigma \eta v+1 \times \beta+0.75 \times \pi \\
& \text { Reparation of a column with spall }=22.67 \times \sigma \lambda+0.33 \times \varepsilon \beta+270 \times \sigma \tau+10 \times \sigma \eta+ \\
& 25 \times \sigma \eta v+0.33 \times \beta \\
& \text { Reparation of a beam with spall }=23.91 \times \sigma \lambda+0.0572 \times \varepsilon \beta+0.8 \times \sigma \tau+0.009 \times \beta+ \\
& 0.18 \times \pi
\end{aligned}
$$

- $\quad$ Reparation of a column with crack $=36.48 \times \sigma \lambda+4.8 \times \imath+0.015 \times \varepsilon \pi+4.8 \times \pi$ Reparation of a beam with crack $=38 \times \sigma \lambda+6.75 \times \imath+0.015 \times \varepsilon \pi+6.75 \times \pi$ Retrofit

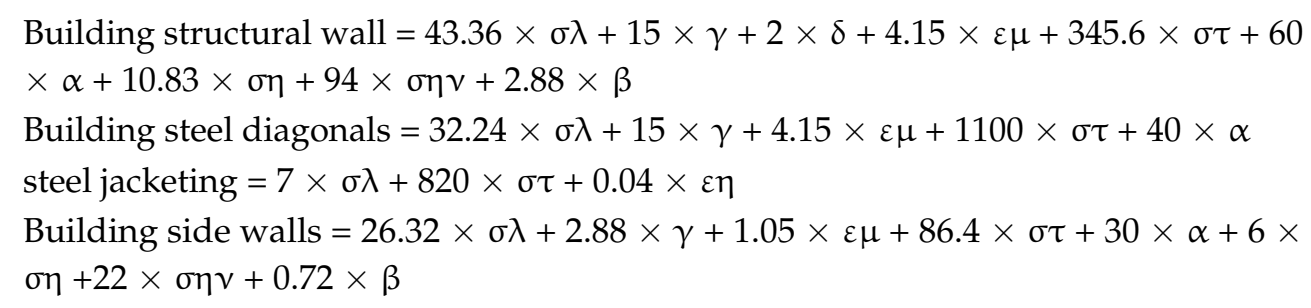

The country dependent unknowns are:

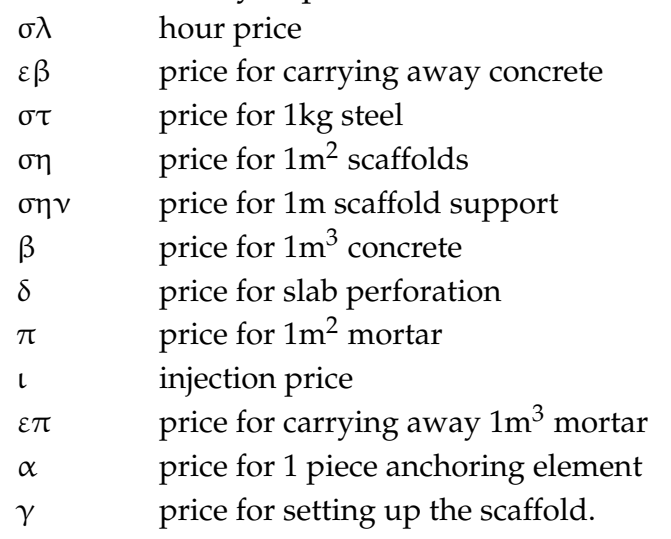

Numerical simulation was performed for the building typology considered for successive earthquakes, selected in a deterministic way (1977, 1986 and two for 1991 from Vrancea, Romania, and respectively, 1978 Thessaloniki, Greece), considering also the case when retrofitting is done 
between two earthquakes. They were computed according to the performance criteria available in fibre-based software, a flow being designed to edit data from this simulation software in spread sheets (Figure 3). A fibre-based software means that instead of modelling beams and columns as an element with plastic hinges at the ends, they are modelled uniformly, based on a system of "fibres" in the section, thus allowing us to see where the fibre fails to meet the requirements. It is this fibre-based analysis which allowed the stress-strain based study on which the innovative part of this research is based. In fibre-based modelling, the beam and column are subdivided, following finite elements modelling into four parts each. The parts where the steel or the concrete fail are identified; these are typically the end parts.

The innovative part of this study relies on a stress-strain based approach applied to building models of this size. Such an analysis yields not only a description of failure mode and determination of limit states eventually reached by the building, but also the specific determination of the number and, if necessary, the position of structural members that suffer different types of damage. This kind of output can form the input for other interdisciplinary studies. The economic study regarding the need for retrofitting/repairing damaged elements, as opposed to preventive retrofitting, was of particular interest for the author. In this sense, an issue for further research, which has been only marginally discussed within this work, is the retrofitting of previously damaged structures; this is an issue which perfectly fits the methodology which has already been proposed and validated.

From devices to costs, there is an option of using the Project Management software (considering all costs transformed in time). 


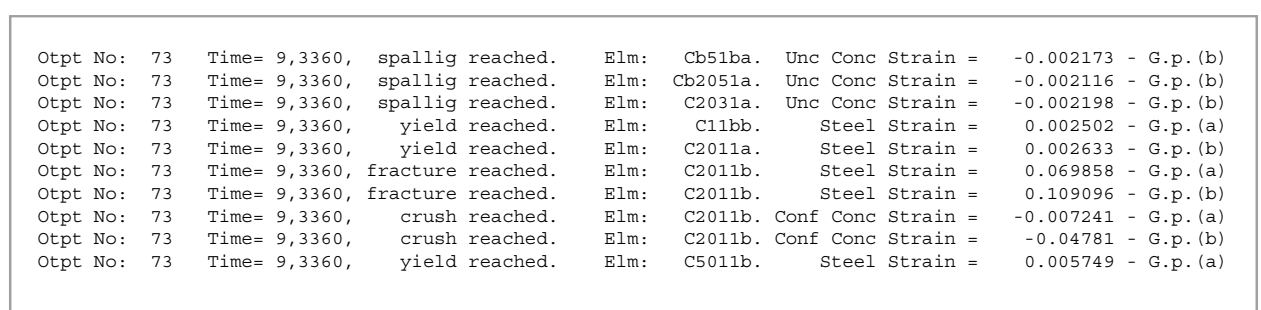

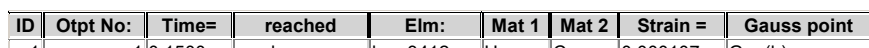

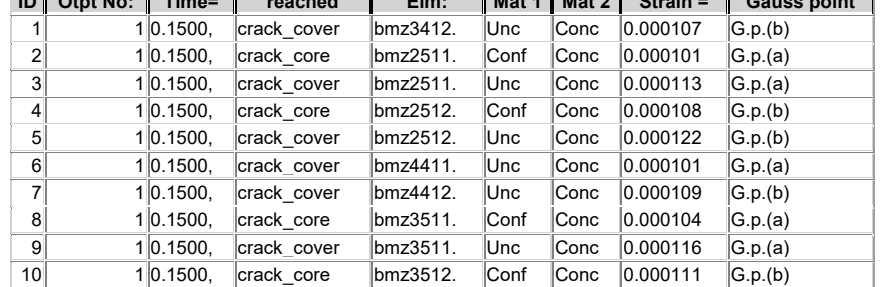

Typical log-file output
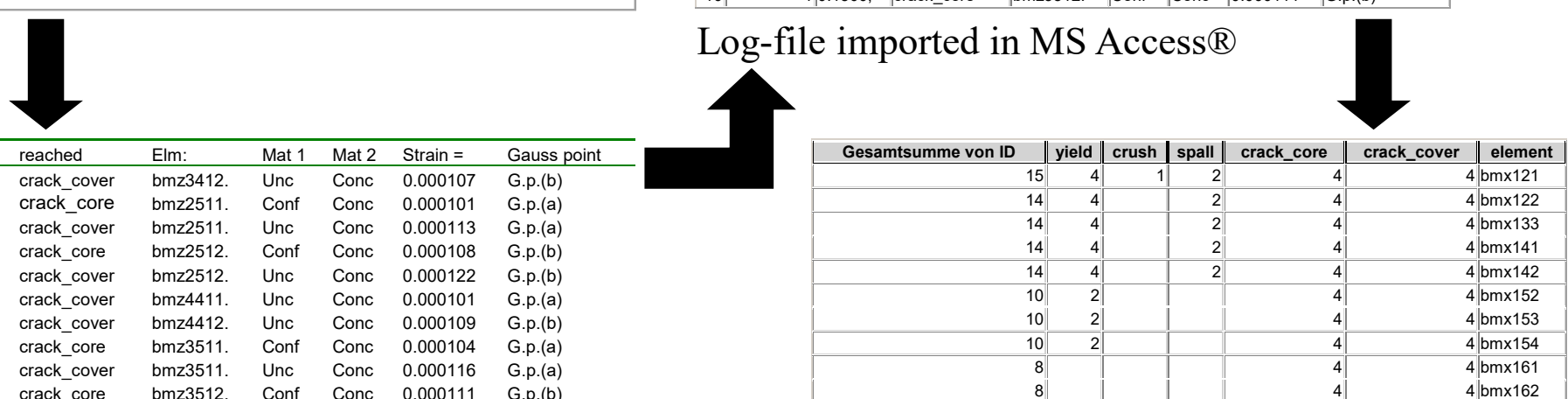

Log-file output imported in MS Excell $\mathbb{R}$

MS Access ${ }^{\circledR}$ query

Figure 3. Algorithm of computations. 


\section{Results}

\subsection{Structural Damage}

The method we developed in this work allows us to count the damaged elements, depending on the damage extent, and thus, to calculate the costs for the entire building. The method also allows us to localise the damaged elements, and thus, to determine if the simulation is in line with the real damages suffered by the buildings during an earthquake. Table 2 and Figure 4 show the number of damaged elements in the whole building of the so-called "Gregor" model in different earthquakes, as well as the cumulative damage obtained with SeismoStruct, applying the algorithm in Figure 3.

Table 2. Structural damage results after [16]. (b) Details of the predicted damaged elements for the Model "Gregor", not retrofitted, using a fine grid, following the 1977 Vrancea earthquake (bmx means beam in $\mathrm{x}$ direction, and bmz means beam in $\mathrm{z}$ direction; $\mathrm{y}$ is the vertical direction of the column in the SeismoStruct software; the columns and the beams can be identified by following their nodes).

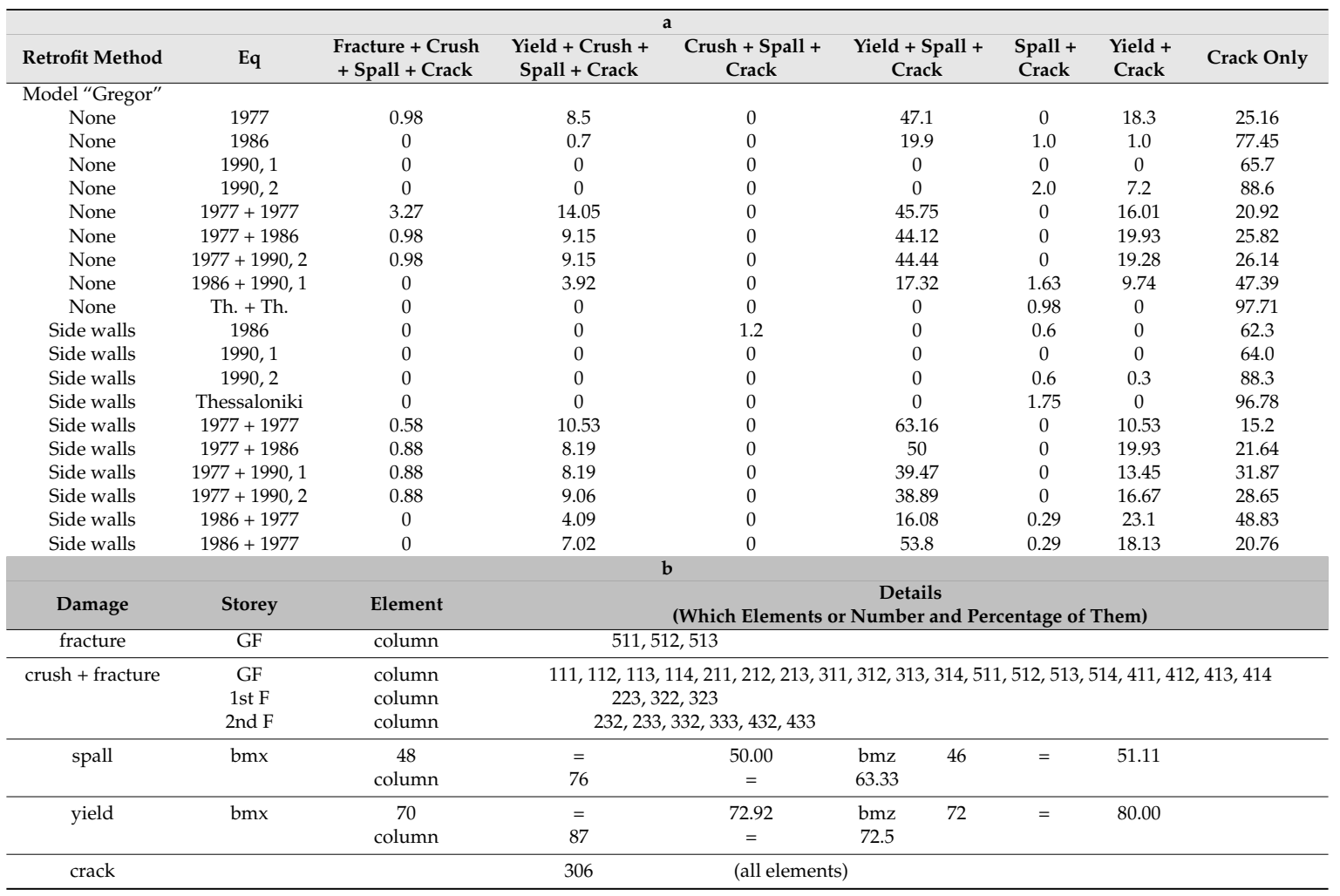




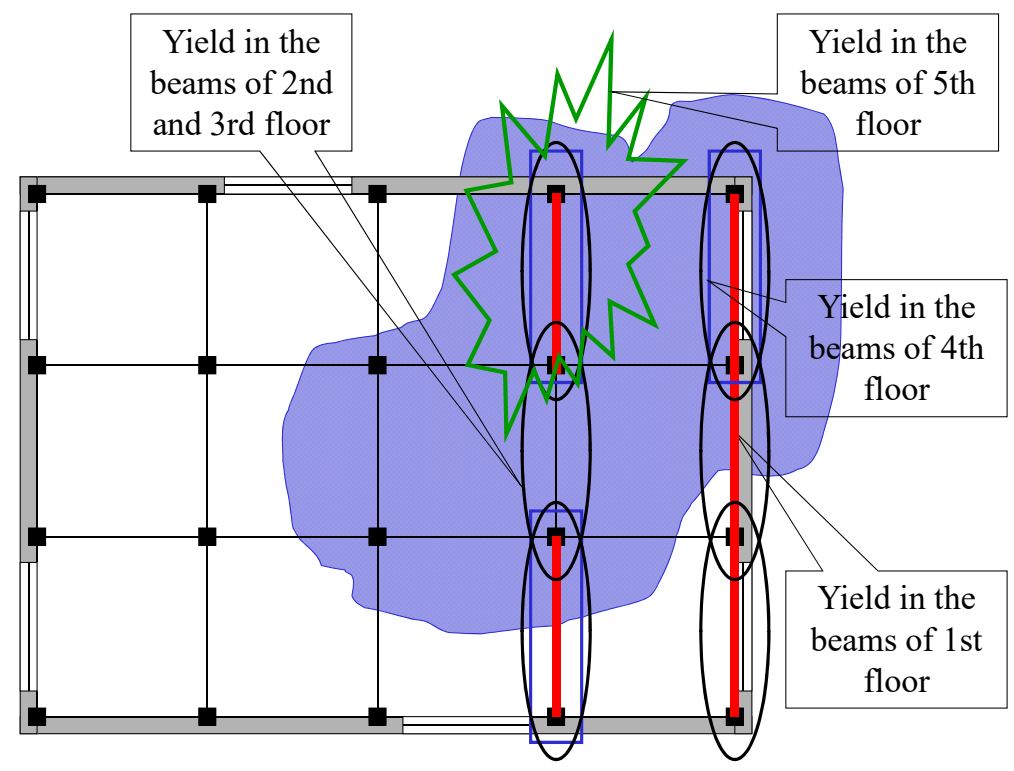

Figure 4. Example of localisation of damage.

\subsection{Comparison of Costs}

Figure 5 shows retrofit alternatives for which costs curves have been generated. A comparison of costs for different earthquakes, comparisons with the costs of rebuilding and, as a result, the computation of the savings done in repair costs by applying the retrofit before the earthquake or before a second earthquake affecting a pre-damaged, or respectively a pre-retrofitted building, was done for:

- Retrofit techniques (braces, jacketing, structural wall, side walls-on the so-called model "Gregor", see sketches in Table 4)-seen earlier also with regards to percentages. These measures should lead to greater strength.

Retrofit strategies (for a selected method: increasing amount and position of steel braces in reinforced concrete frames-on the so-called model "Özzi", see sketches in Table 5). Increasingly, more rigidity is obtained.

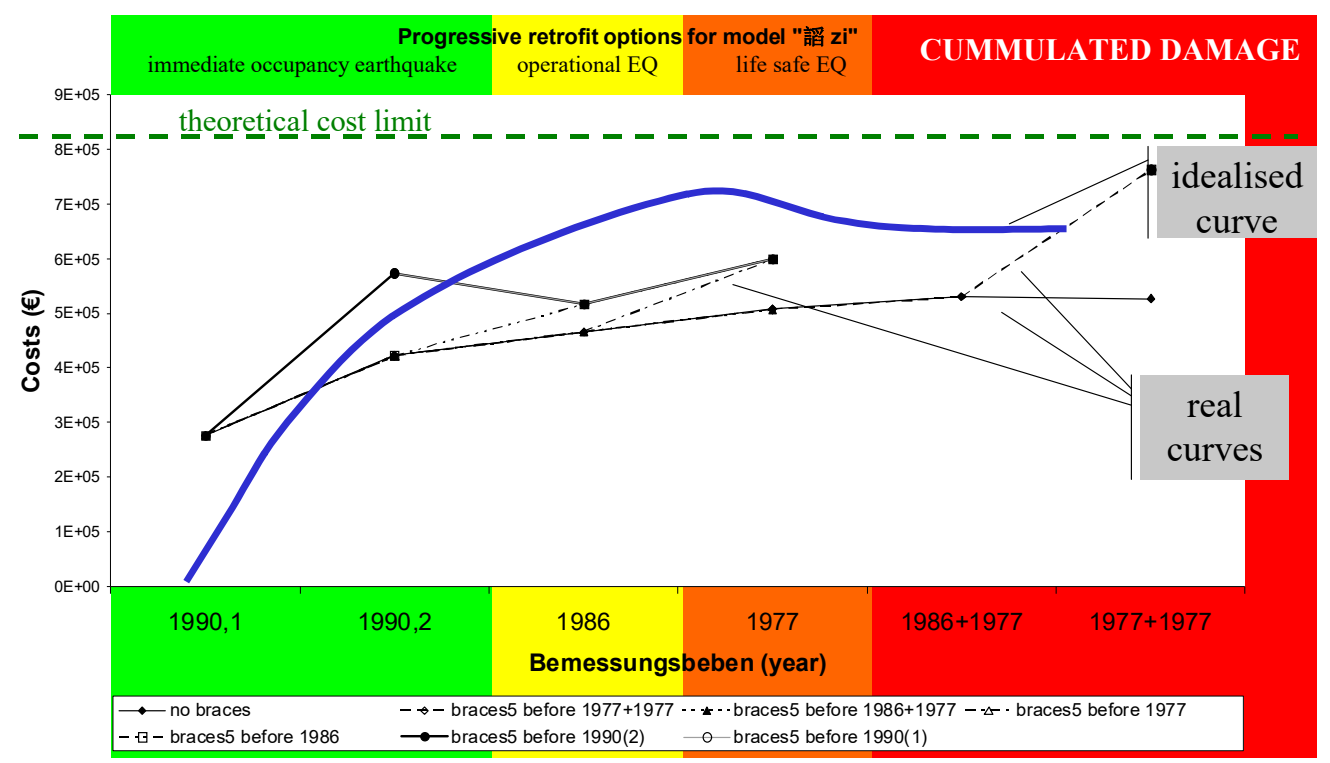

Figure 5. Costs curves of retrofit alternatives [15]. 
In order to be able to assess economic efficiency, the preventive retrofit was compared to post-earthquake repair (costs before and after the earthquake). The following retrofitting scenarios were considered:

- The new building is designed to be earthquake safe, and the non-damaged building is retrofitted

- $\quad$ The pre-damaged buildings is retrofitted (in case of a second applied earthquake)

- $\quad$ The collapsed building is demolished and replaced by a seismically resistant new building.

In case of successive earthquakes to which the structure is subjected, higher costs of the preventive (pre-earthquake) retrofitting lead to a reduction in damage from earthquake, and thus, to the reparation costs arising there from. With the addition of the curves and the total shape, we sought to make this notion visible.

Table 3 shows the results from the analysis of the structure, with the application of the economic efficiency study. These studies depend upon more indicators, such as the relationships between:

- $\quad$ Reparation/new erection (where the costs for new building were computed based on surface indicators, for the whole building, not only the structure)

- Retrofit/new erection

- Reparation/retrofit

- $\quad$ Reparation saving/retrofit

A brace retrofitting method was selected because it was considered to be inspired from the local seismic culture of another type of skeleton buildings, i.e., half-timbered buildings. Also, we note that in early post-war Romania, a variant of RC diagonal braces was developed, as seen in the WHE report. In Italy on the other hand, variants were developed to apply active seismic protection measures on steel braces; we developed a prototype on how this could be in agreement with interwar typologies, for example De Stijl.

Energy dissipaters were first applied by Fip industriale in 2000 in Italy, after the 1997 earthquake in Umbria and Marche, to monument-listed school buildings, including the 1950 Gentile Fermi school of Fabriano, Ancona, which was in the interwar rationalist style. This was also the case for the 1950 Perticari lyceum of Senigallia, Ancona province, central Italy, which was affected by the 2002 Molise earthquake. In the first case, the diagonals are visible from outside, penetrating the walls, with special attention to the windows, while in the latter, these are hidden inside the brick facade which is intact, and therefore, dependent upon other mechanisms of dissipation. Two schools of Potenza: Scuola Domiziano Viola and Luigi La Vista, were retrofitted in 2010.In the first case, coloured diagonals which are visible in the exterior façade, and inserted windows adapted to them [33], like in our De Stijl pavilion, were used. Potenza is located in one of the most active seismic areas of southern Italy, where the "casa baraccata" was introduced. Strengthening school buildings is a priority in Italy [34]. Tobriner [35] noted the historical role of diagonals against earthquakes. Diagonals should be used more often and more creatively for reinforced concrete, but also for timber and metal. Charleson et al. [36] investigated the artistic expression of diagonals in concrete, to which we referred in the chapter about modelling the pavilion space structure. This was done in connection with the implementation and performance of this system in an earthquake in Mexico in 1985 [37]. 
Table 3. Results of costs efficiency (after [16]).

\begin{tabular}{|c|c|c|c|c|c|c|c|c|c|c|c|c|c|c|c|}
\hline Model & Retrofit & $\begin{array}{c}\text { Earthquake } \\
1\end{array}$ & $\begin{array}{c}\text { Earthquake } \\
2\end{array}$ & Repair (€) & Retrofit $(€)$ & Total (€) & New built (€) & $\begin{array}{c}\text { Repair/New } \\
\text { Built }\end{array}$ & $\begin{array}{c}\text { Retrofit/New } \\
\text { Built }\end{array}$ & $\begin{array}{l}\text { Total/New } \\
\text { built }\end{array}$ & $\begin{array}{c}\text { Total/New } \\
\text { Built-0.30 }\end{array}$ & Repair/Retrofit & Retrofit/Repair & $\begin{array}{l}\text { Difference to } \\
\text { Non } \\
\text { Retrofitted (€) }\end{array}$ & $\begin{array}{c}\text { Repair } \\
\text { Saving/Retrofit }\end{array}$ \\
\hline Özzi & - & 1977 & - & 506,950 & 0 & 506,950 & $1,561,534$ & 0.32 & 0.00 & 0.32 & 0.02 & - & 0 & - & \\
\hline Özzi & - & 1977 & 1977 & 526,850 & 0 & 526,850 & $1,561,534$ & 0.33 & 0.00 & 0.33 & 0.04 & - & 0 & - & \\
\hline Özzi & - & Salonika & & 422,000 & 0 & 422,000 & $1,561,534$ & 0.27 & 0.00 & 0.27 & -0.03 & - & 0 & - & \\
\hline Özzi & - & Salonika & Salonika & 423,050 & 0 & 423,050 & $1,561,534$ & 0.27 & 0.00 & 0.27 & -0.03 & - & 0 & - & \\
\hline Özzi & Braces 1 & 1977 & - & 544,400 & 74,785 & 619,185 & $1,561,534$ & 0.34 & 0.04 & 0.39 & 0.10 & 7 & 0.13 & 0 & 0 \\
\hline Özzi & Braces 1 & 1977 & 1977 & 595,400 & 74,785 & 670,185 & $1,561,534$ & 0.38 & 0.04 & 0.42 & 0.13 & 8 & 0.12 & 0 & 0 \\
\hline Özzi & Braces 1 & Salonika & - & 422,000 & 74,785 & 496,785 & $1,561,534$ & 0.27 & 0.04 & 0.31 & 0.02 & 6 & 0.17 & 0 & 0 \\
\hline Özzi & Braces 1 & Salonika & Salonika & 479,850 & 74,785 & 554,635 & $1,561,534$ & 0.30 & 0.04 & 0.35 & 0.06 & 6 & 0.15 & 0 & 0 \\
\hline Özzi & Braces 2 & 1977 & - & 553,050 & 67,987 & 621,037 & $1,561,534$ & 0.35 & 0.04 & 0.39 & 0.10 & 8 & 0.12 & 46,100 & 1 \\
\hline Özzi & Braces 2 & 1977 & 1977 & 605,250 & 67,987 & 673,237 & $1,561,534$ & 0.38 & 0.04 & 0.43 & 0.13 & 9 & 0.11 & 78,400 & 1 \\
\hline Özzi & Braces 2 & Salonika & - & 477,100 & 67,987 & 545,087 & $1,561,534$ & 0.30 & 0.04 & 0.34 & 0.05 & 7 & 0.14 & 55,100 & -6 \\
\hline Özzi & Braces 2 & Salonika & Salonika & 478,800 & 67,987 & 546,787 & $1,561,534$ & 0.30 & 0.04 & 0.35 & 0.05 & 7 & 0.14 & 55,750 & 1 \\
\hline Özzi & Braces 3 & 1977 & - & 580,950 & 67,987 & 648,937 & $1,561,534$ & 0.37 & 0.04 & 0.41 & 0.12 & 9 & 0.11 & 74,000 & 1 \\
\hline Özzi & Braces 3 & 1977 & 1977 & 606,650 & 67,987 & 674,637 & $1,561,534$ & 0.38 & 0.04 & 0.43 & 0.13 & 9 & 0.11 & 79,800 & 1 \\
\hline Özzi & Braces 3 & Salonika & - & 473,900 & 67,987 & 541,887 & $1,561,534$ & 0.30 & 0.04 & 0.34 & 0.05 & 7 & 0.14 & 51,900 & 1 \\
\hline Özzi & Braces 3 & Salonika & Salonika & 476,700 & 67,987 & 544,687 & $1,561,534$ & 0.30 & 0.04 & 0.34 & 0.05 & 7 & 0.14 & 53,650 & 1 \\
\hline Özzi & Braces 4 & 1977 & - & 455,100 & 135,973 & 591,073 & $1,561,534$ & 0.29 & 0.08 & 0.37 & 0.08 & 3 & 0.29 & $\begin{array}{l}-51,850 \\
\end{array}$ & -0 \\
\hline Özzi & Braces 4 & 1977 & 1977 & 596,400 & 135,973 & 732,373 & $1,561,534$ & 0.38 & 0.08 & 0.46 & 0.17 & 4 & 0.22 & 69,550 & 1 \\
\hline Özzi & Braces 4 & Salonika & - & 345,850 & 135,973 & 481,823 & $1,561,534$ & 0.22 & 0.08 & 0.30 & 0.01 & 3 & 0.39 & $-76,150$ & -1 \\
\hline Özzi & Braces 4 & Salonika & Salonika & 408,900 & 135,973 & 544,873 & $1,561,534$ & 0.26 & 0.08 & 0.34 & 0.05 & 3 & 0.33 & $-14,150$ & -0 \\
\hline Özzi & Braces 5 & 1977 & - & 422,950 & 176,765 & 599,715 & $1,561,534$ & 0.27 & 0.11 & 0.38 & 0.08 & 2 & 0.41 & $-506,950$ & -3 \\
\hline Özzi & Braces 5 & 1977 & 1977 & 586,250 & 176,765 & 763,015 & $\begin{array}{l}1,01,034 \\
1,561,534\end{array}$ & 0.37 & 0.11 & 0.48 & $\begin{array}{l}0.00 \\
0.19\end{array}$ & 3 & $\begin{array}{l}0.41 \\
0.30\end{array}$ & 59,400 & 0 \\
\hline Özzi & Braces 5 & Salonika & - & 442,600 & 176,765 & 619,365 & $1,561,534$ & 0.28 & 0.11 & 0.39 & 0.10 & 3 & 0.39 & $-422,000$ & -2 \\
\hline Özzi & Braces 5 & Salonika & Salonika & 476,700 & 176,765 & 653,465 & $1,561,534$ & 0.30 & 0.11 & 0.41 & 0.12 & 3 & 0.37 & 53,650 & 0 \\
\hline
\end{tabular}

Salonika stays for Thessaloniki. 


\subsection{Output for the Decision System}

Costs have to be balanced against benefits. Benefits remain the priority, and define the purpose of the intervention; otherwise, there would be a zero option. Benefits can be compared among different retrofitting techniques and strategies, or compared to the status quo (i.e., no measures taken).

Four categories of actors were considered: the (structural) engineer, the architect, the investor, and the user (Figure 6). The first three belong to the category of experts, while the fourth makes the decision democratic/participative through the roles of the affected people. A comparison was made with two out of four methods [38]:

- Pair wise comparison-derived from the Saaty, and applied to our construction related problem Strassert. In this method, costs are ranked numerically, while criteria for other actors may be ranked qualitatively or quantitatively (Table 4). K1 represents the costs, while K2, K3 and K4 are benefit criteria in benefit-costs analyses. $\mathrm{K} 2$ refers to the less damaged structural elements (criterion of the civil engineer), $\mathrm{K} 3$ to the influence on the appearance of the building (criterion of the architect), and $\mathrm{K} 4$ to the possible need for relocation, in the project management of the measure, or in the retrofit strategy (criterion of the user). The latter two are on a scale which is not numerically measurable. In Figure 6, these were all quantified and had sub-measurement spaces, which can be introduced into the software using the given ontology. In Table 5 and Figure 7, the criterion of costs which has to be compared with the other three benefit criteria is detailed. As described, two models were considered: retrofit elements alternatives for the so-called "Gregor", and retrofit strategies alternatives for the so-called "Özzi". In the second case, the amount of retrofit elements increased. Apart of these idealised models, the model of a real interwar building, called "Interbelic" (Figure 1b.) was considered. First, the given earthquake was applied to the non-retrofitted building, then to the building after retrofitting; the difference in costs for repair was then included in the table. In the case of the occurrence of two successive earthquakes, the retrofit was applied after the first earthquake. The repair costs for the real building are much higher. Given the complexity of the structure, the level of the damages are accordingly high. At earthquakes of lower intensity, such as those of 1986 and 1990, the savings are negative, which means that the retrofit before the earthquake led to increased costs compared to that of repairs after the earthquake. This is why the amount of retrofitting has to vary according to the expected earthquake, as the concept of cost curves shows, depending on the life time of the building.

- Utility value method. For this method we again applied the classification of Bogenstätter, with its own developed criteria (Figure 6). Costs enter the measurement spaces of some criteria. As with a SWOT analysis, some opportunities strengthen each other, while some problems exacerbate one other. Here, qualitative criteria have to be converted into quantitatively measurable units. In a further step, we developed an ontology for the way of developing a computer application for this purpose, considering both the decision tree and the measurement spaces for the criteria. 


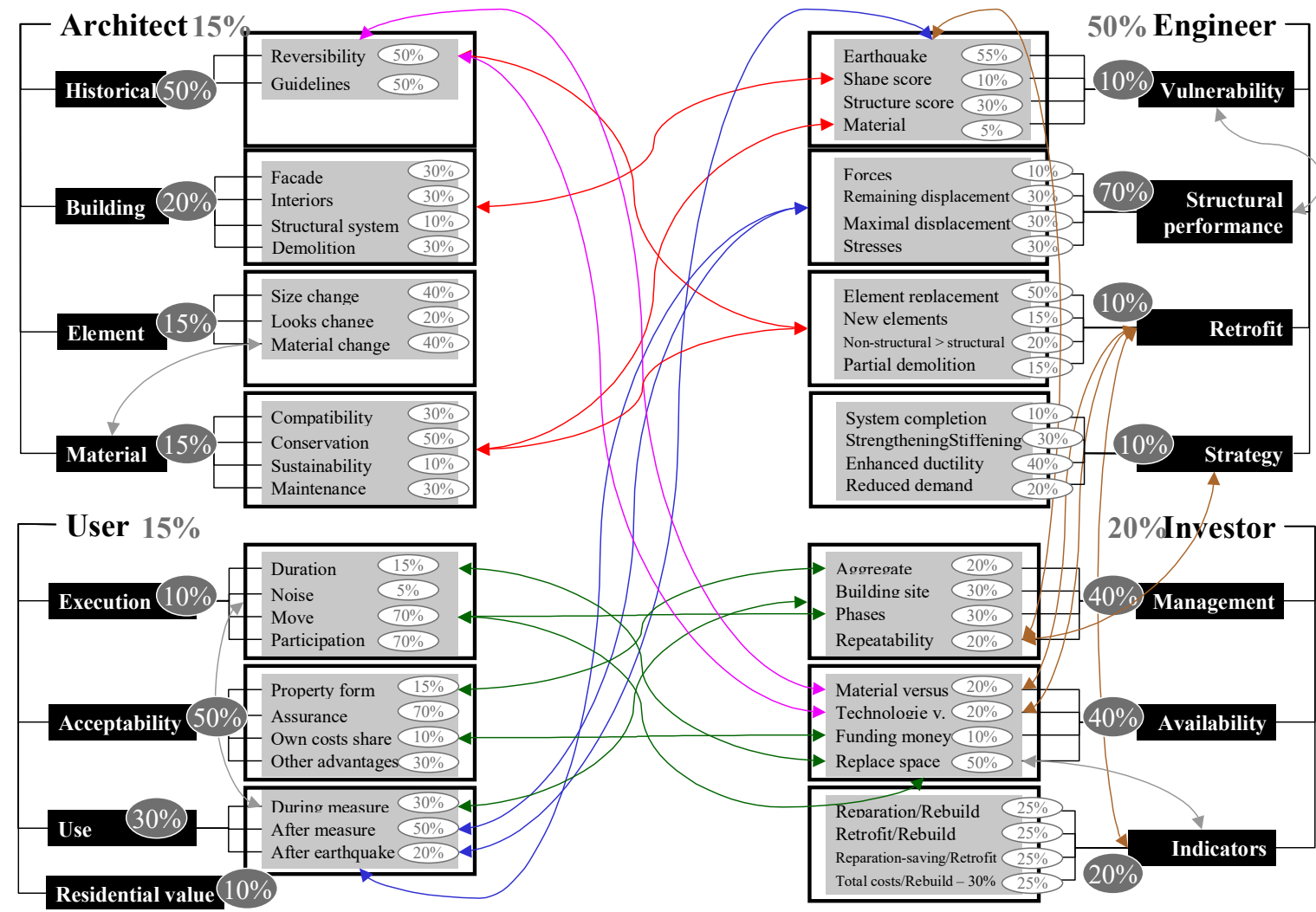

(a)

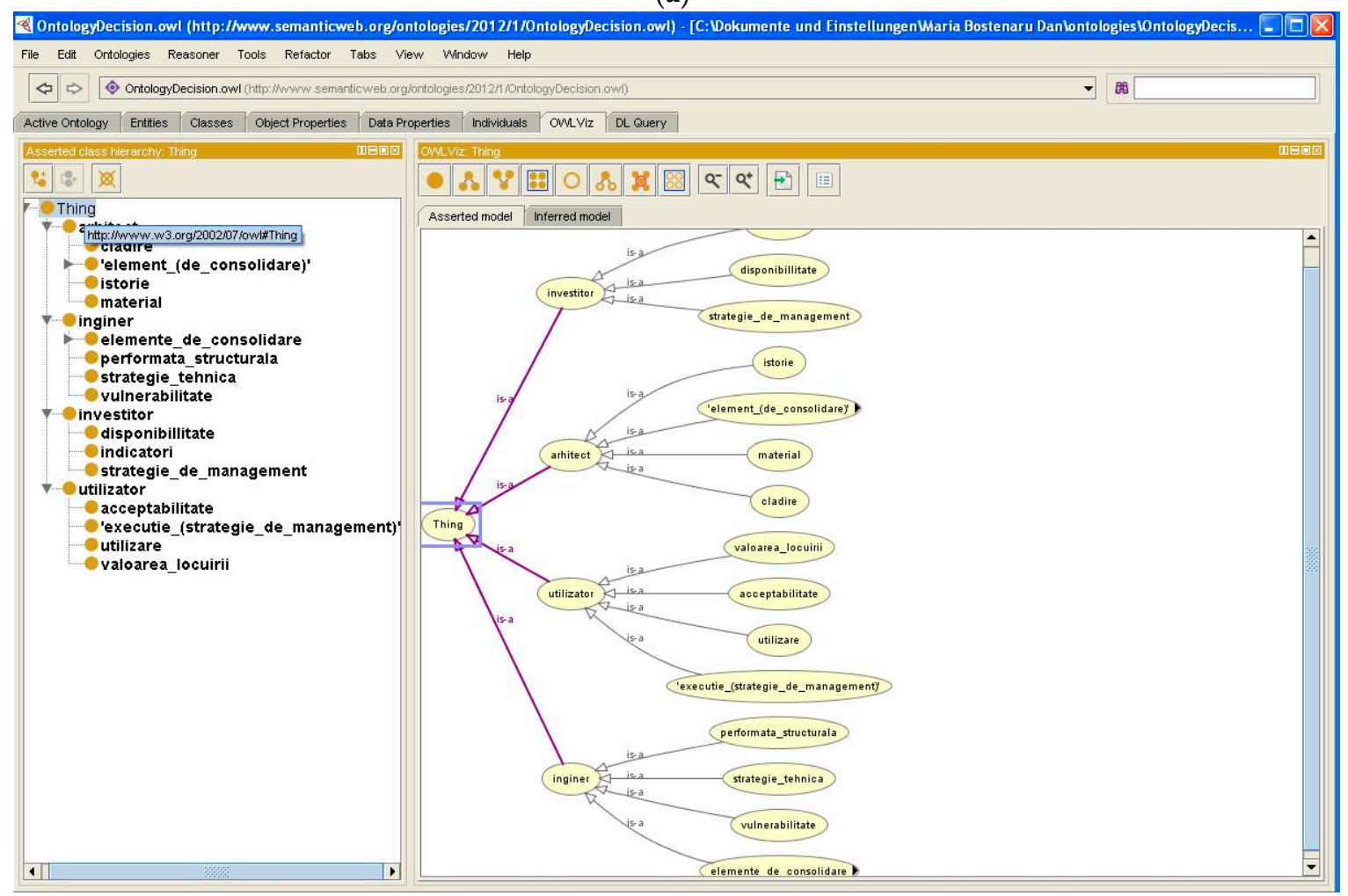

(b)

Figure 6. Decision tree among the envisaged actors (a) actors, criteria and weighting, ontology for the decision tree $(\mathbf{b})$. 
Table 4. Pair wise comparison.

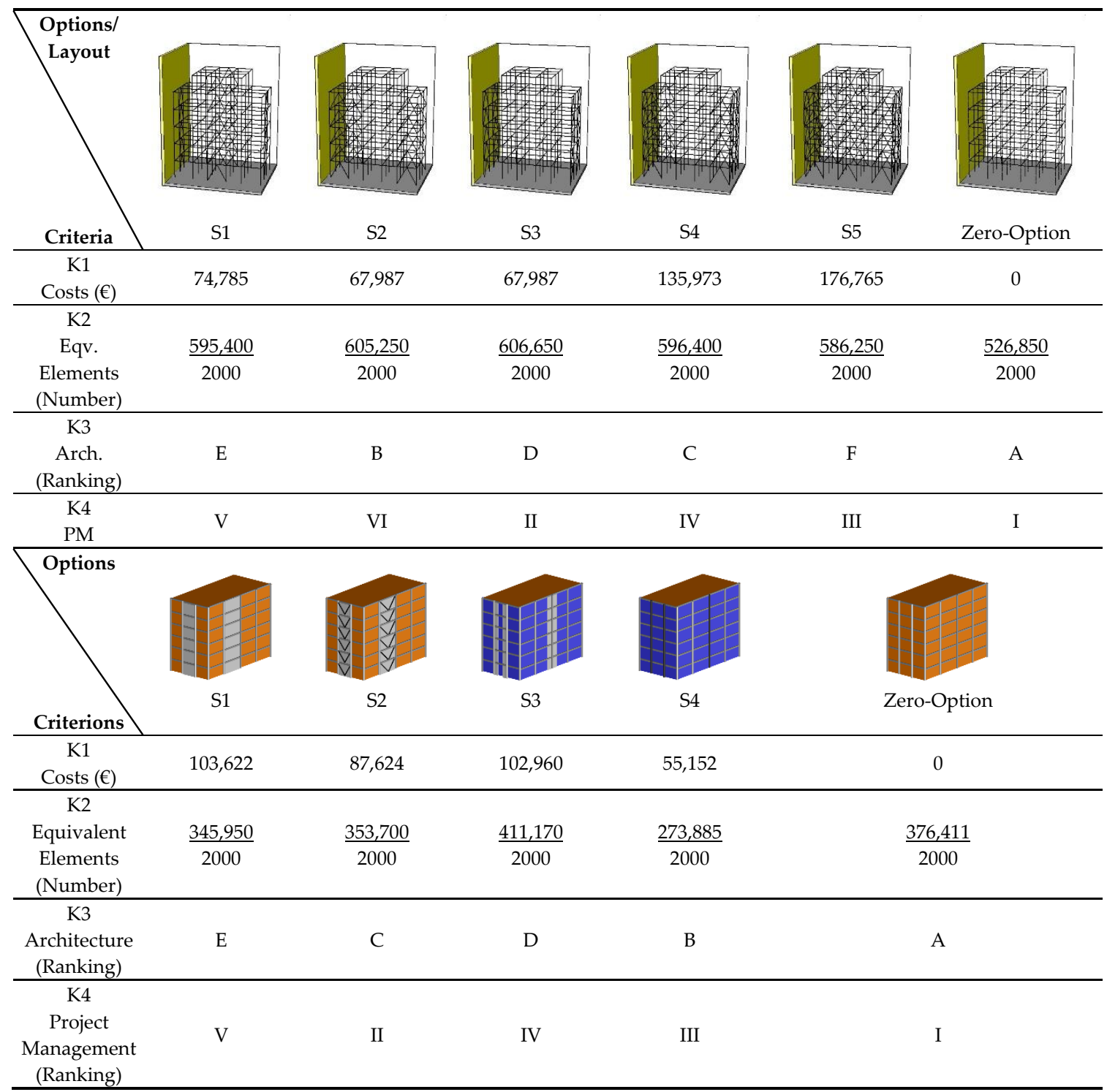

Table 5. K1 Savings in costs in pre-earthquake retrofit compared with post-earthquake reparation in $€$ detailed for all models.

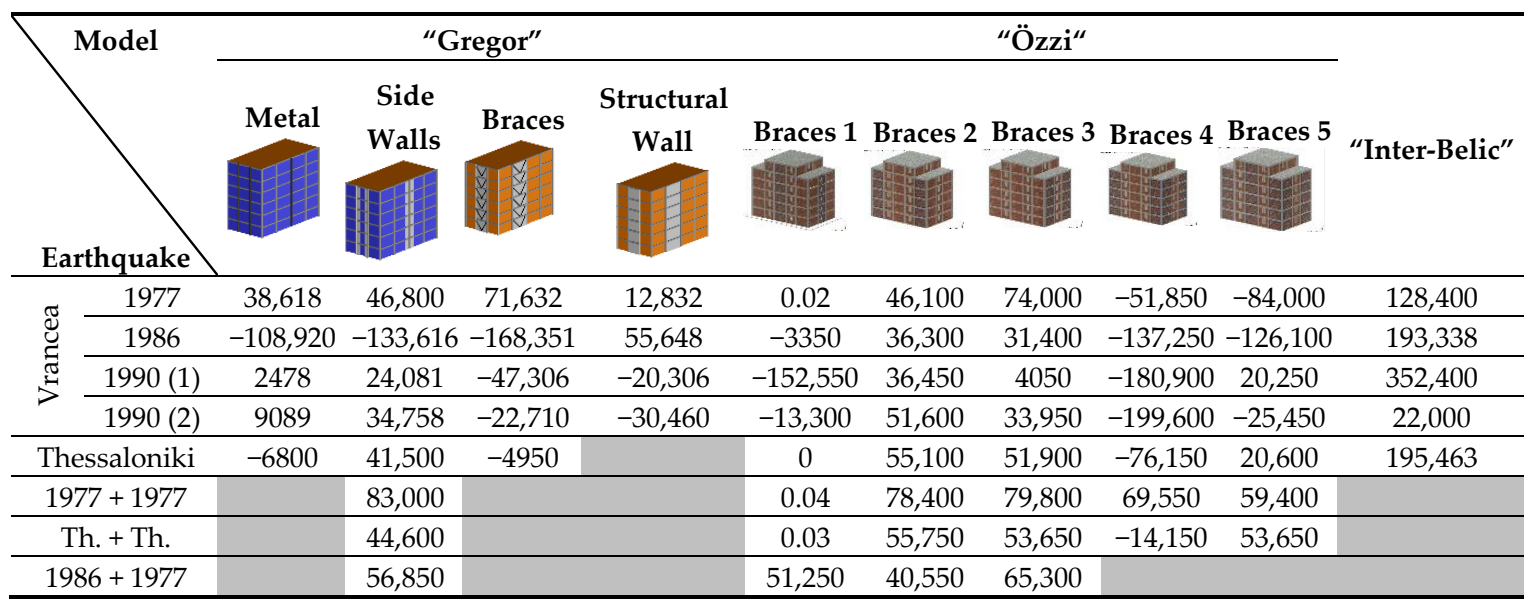


Returning to the issue of democratisation, Figure 6a shows how these categories of experts are related to each other, and to the problem of cost-benefit analyses, including the issue of retrofitting elements, building, and urban scale. The decision tree has, on its first level, the four considered actors, and on the next level, their criteria, which have been weighted; their measurement spaces on different scales are taken into account.

All criteria form the taxonomy of decision making. Among them, there are different ways to make the cost-benefit analysis, from a weighted tree to a pair-wise comparison. The taxonomy was modelled as a decision tree, which forms the basis for ontology (Figure 6b). This ontology represents a further step to make comparisons to Bostenaru [38]; thoughts on multi-criteria decisions made therein are presented in Figure 6. In this way, computational support for the decision can be achieved. The measurement spaces of the criteria are translated into ontological relationships, while the parent-child relationships are derived from the tree.

Figure 8 is based on the model of Fingerhuth and Koch [28] and Richter (course notes), leading to more complex relationships in the case of earthquake retrofitting. This was superimposed onto the zoom idea between building element, building, and urban scale. Additionally, this presents feedback to the typology analysis in Section 2.2.

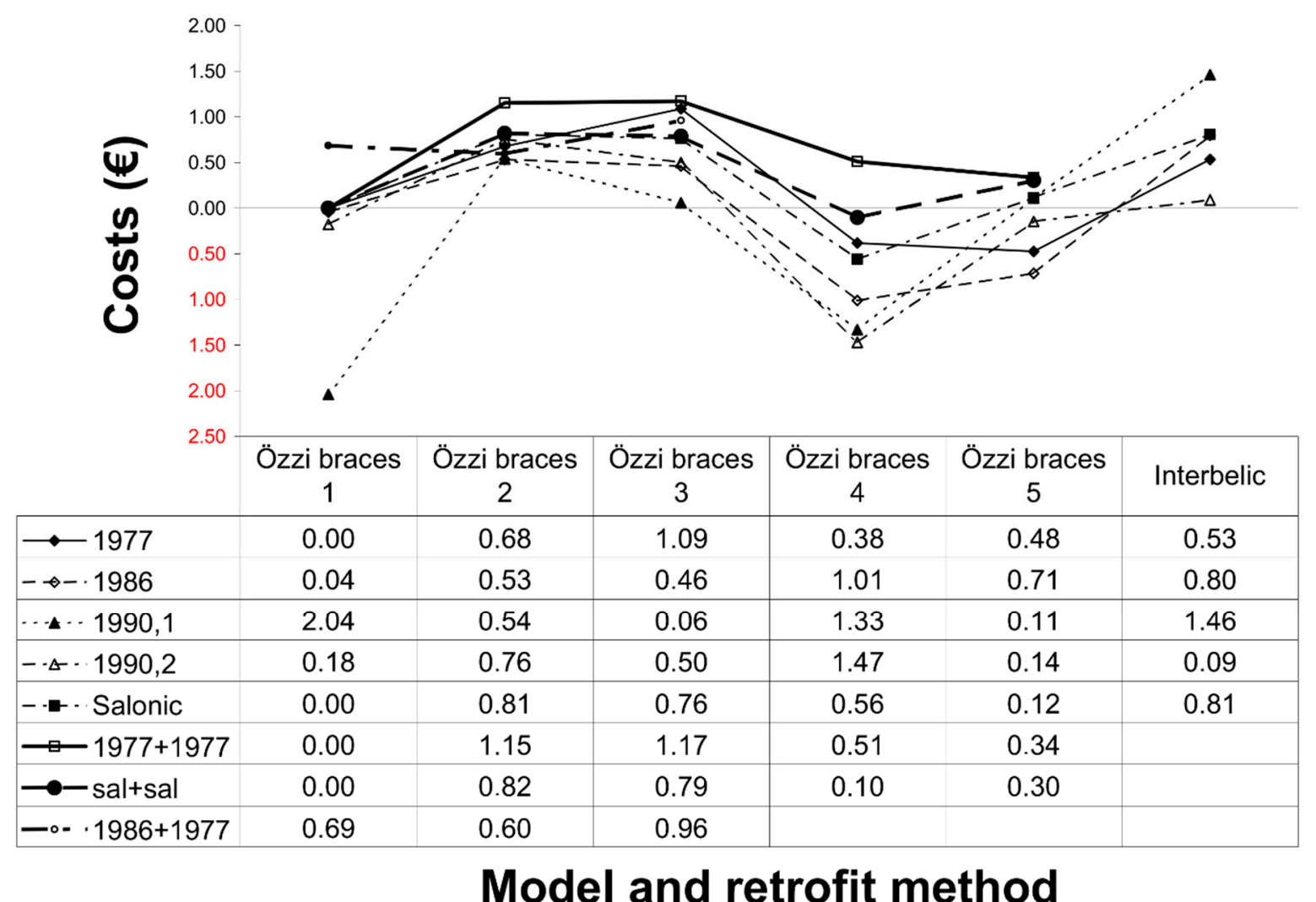

Figure 7. Graphical presentation of the model "Özzi” part in Table 5. 


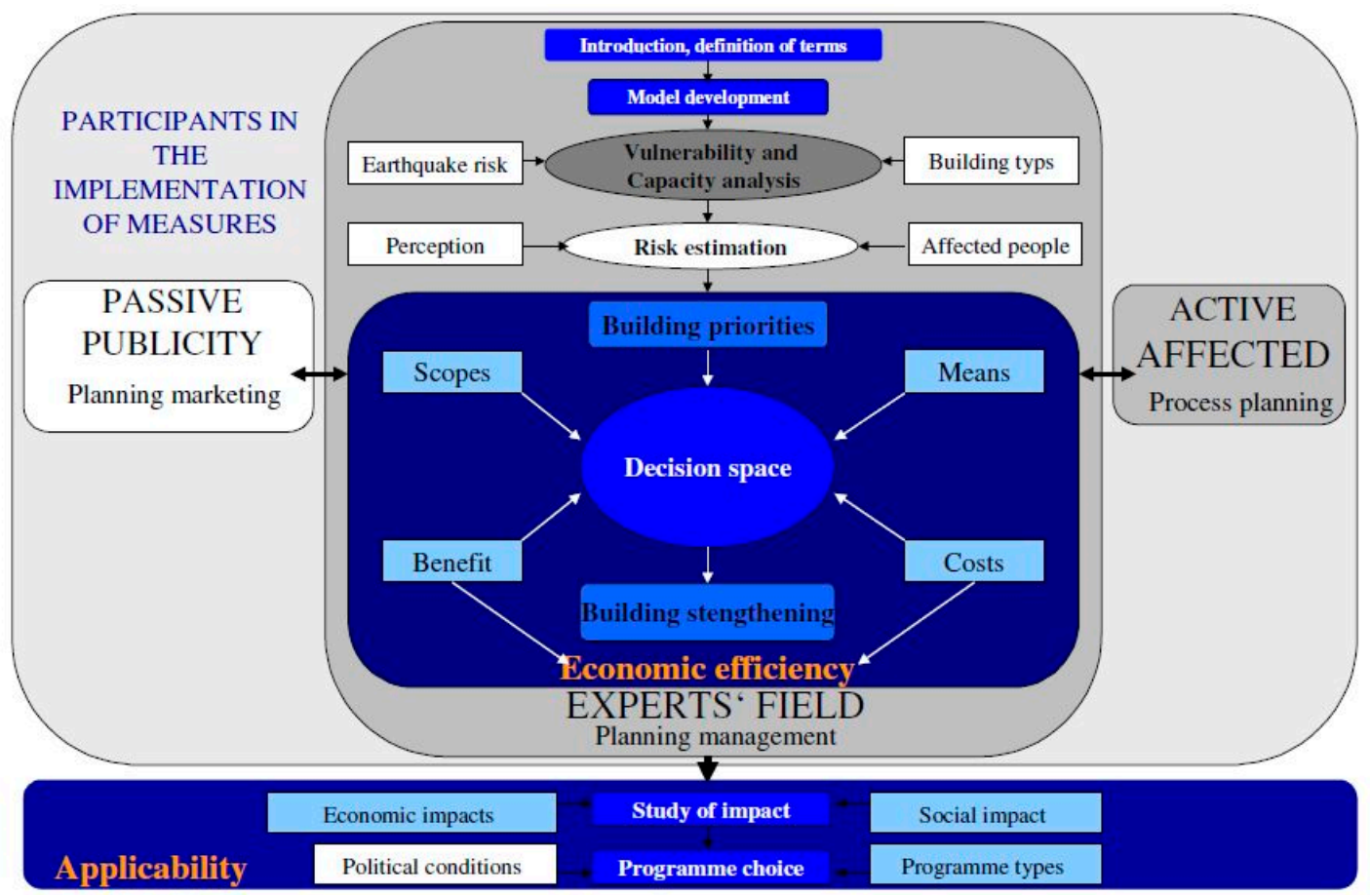

Figure 8. Decision workflow [15].

For such studies as those presented here regarding scale issues, the cost assessment method for new buildings, based on spaces, is adequate, since on such scales, the constructive details, as explained, are not presented.

\section{Discussion}

This study shows a developed concept for an issue in earthquake engineering which has not yet been adequately researched. Fine-tuning is still necessary.

\subsection{Optimisation of the Current Study}

There are some refinements to be done in order to optimise this study.

The current study has been performed using German cost calculation methods, and hourly/material prices, even though Germany is a low to moderately seismically-active country. Taking the prices per hour for labour for the country from where the typology and the measurements originate would improve the study. These are not always available, despite the fact that we developed a flexible computation mean, with no need for databases in order to perform measurements on buildings in those countries.

The structural simulation maybe improved by making the computed curves to meet the idealised ones described in the concept.

Retrofit measures should be optimised for a given earthquake, in order to make correct computations.

In order to assess the costs of rebuilding or making general upgrades without retrofitting, architecture methods for building economics are considered based on floor surface. A further study would allow us to convert device computations on floor surface costs, to be able not only to implement in an ICT environment by means of ontology and BIM, but also to apply them on an urban scale.

One possible method is the use of probabilistic means to extend the study cases to apply to larger urban bases. For the latter, studies of the probabilistic application of structural mechanics models, instead of observation based statistics, can be considered. The economics of retrofitting should include the application of a Monte Carlo simulation to numerical simulations, at building scale, used for the 
calculation of costs using the aforementioned retrofit elements method; comparison with real examples of earthquake retrofitting and associated costs. The study, as it is, is deterministic, as it was the assessment of physical loss in [21], before continuation in [22]. Such further study is envisaged. For the urban area of the protected zone of Magheru however, the mean value may have been met through individual deterministic assessment, given the variance in buildings; for further individual buildings, a detailed study is required in the future. The method is more exact in the structural simulation than that of [21], and is thus more suitable for urban areas. Comparison to the retrofit costs for a real building is envisaged through contact with offices in Greece.

An alternative base for decision makers would be the Plausibility Principle according to ISO 13822:2010 (http:/ / www.iso.org/iso/catalogue_detail?csnumber=46556).

\subsection{Studies of Implemented Retrofit Measures}

The theoretical costs for model measures were compared to the actual costs of retrofits for this building type (with reinforced concrete jacketing and FRP) in Greece. The proposed theoretical measures were generally compared to those applied in practice in Romania and Italy. A further study will include these, since in Italy, diagonal braces with dissipation have been used. The typology of braces is relevant also for the local seismic culture, perhaps demonstrating another type of skeleton structures whose distribution has been studied: the timber skeleton. A subtype of Romanian reinforced concrete skeleton buildings includes diagonal braces (see next issue).

While in this work the emphasis was on the modelling of typical buildings, and on typical retrofit measures, the implementation of such measures in other countries considered shall be investigated as well, and a database created.

In Italy, so far we have identified for Rationalist buildings:

- $\quad$ FRP (Torre delle Nazioni, Napoli)

- $\quad$ Seismic dissipaters (the examples given for Italy in this paper)

In Romania, cutting of corners leads to new plan layouts, an issue we have dealt with (but one that is not the subject of this paper). The most commonly used method is concrete jacketing, even for steel structures.

In Greece, combined methods of FRP for horizontal elements and jacketing for vertical elements were employed both in Athens at the Army Pension Fund building [39] and at a hotel in northern Greece [40].

For structural studies, we may consider collecting structural data from experiments databases, such as the databases of tests on laboratory models (NEEShub online Project Warehouse http://nees.org/warehouse/search; European Laboratory for Structural Assessment/ELSA database; a forerunner of several European laboratories databases which are to be integrated according to the US model in the Seismic Engineering Research Infrastructures for European Synergies/SERIES database http:/ /www.series.upatras.gr/ebase; [41]).

\subsection{Relationship to Earlier RC Structures}

The focus of this work was on interwar RC structures: the RC skeleton. If, in Romania, earlier RC structures, such as Hennebique structures are rare, in Italy they were introduced by extensive use by the Porcheddu community. A pre-study of the distribution of predecessors in Europe has been already undertaken.

Differences and common features have to be put into the context of earthquake vulnerability. Hennebique systems performed better, because secondary beams were contained in a regular grid, unlike those in Romania. Creating such a grid is an issue of structural morphology that is derived from urban morphology, and will be the subject of a future study. 


\subsection{Relationship to Timber}

We have already mentioned the choice of diagonal braces as a preferred method to be investigated through the relationship to timber. We have done preliminary research on a language for reinforced concrete from timber, e.g., in essays of the architects in the early XXth century. Lessons to be learned from half-timbered housing can also be learned for reinforced concrete, although a similar study of the geographic distribution of half-timbered construction leads to the preliminary conclusion that it is not necessarily the local seismic culture, but rather, the availability of appropriate timber resources, that leads to the occurrence of a given typology in a specific region. A review of the literature on bracing as a retrofitting method revealed that it has already been successfully employed in Mexico, and that there is, as mentioned, a local seismic culture in reinforced concrete bracing in Romania; frequent application is also observed in projects realised in Italy with active dissipation methods. Computations for steel must be compared.

\subsection{Computer Games}

One training method for the pre-disaster phase might be computer games. For the genre of computer and management games, there is an economic component which can be derived from this research.

At an urban scale, SimCity also involves early phase disaster scenarios, such as the 1906 San Francisco Earthquake. Today, such concepts are used by SimTorino, and we will investigate the patent pending application when such an occasion is given (personal communication Luca Caneparo). For building scales, games following the Ken Follett novels use construction management components; in the case of "World without End", they also involve natural catastrophes.

We had the opportunity to compare hard paper to digital representation in the investigation of the game "Pillars of the Earth". The game is dedicated to the architectural endeavours of the construction of a cathedral using resources, such as people and materials, as in construction management. The advantage of such a digital method is the better implementation of the rules of the game. Although they may be useful for our general research on project management, it was a good way of introducing us to the comparison between the "material" and "digital", leading to a conclusion in the material and 3D models which later led to the developed concept. Also, in games, we have to deal with the symbolic dimension, while ignoring issues of scale. The church which has to be built in "Pillars of the Earth" follows two different approaches: in the "material" version, it is made of simple volumes which are put one next to the other, like in building a model at an urban scale for architects, or in building a model in Google's Building modeler. Jeffrey Head, a former guest at the Canadian Centre for Architecture, observed how digital tools such as SketchUp are the toys of today in stimulating the imagination of architects. In the "digital" version, the church is built as it would be with a 3D printer. The game teaches how to deal with construction in the same way that it is dealt with in civil engineering. A building consists of devices for its elements. However, when doing project management in architecture, at the overall scale, the spaces are considered, building elements coming into question at the detail scale (the $\mathrm{m}^{3}$ of built space or the $\mathrm{m}^{2}$ of floor space for a different function determine the costs, and not the resources).

The socio-economic models of construction management games will be considered, both computer games and board games, starting with SimCity, in order to see how the necessary resources can be modelled.

It is worthy of mention that game theory is adequate for collaborative decisions in natural disaster protection, through the so-called bar-gaining method. Also, rendering the necessary materials and people abstracts can be adapted from the devices used in the construction management that was described earlier. This is subject of another publication. 


\section{Conclusions}

An original methodology for the calculation of costs was developed, based on available project management methods and software possibilities. The method is applicable for single buildings of the type considered here (RC skeleton buildings from the interwar period).

The building typology being studied represents a heritage across Europe in seismic and non-seismic countries. Apart from Romania, this typology can be found in Portugal, Italy and Greece, among others, as the research in the project CA'REDIVIVUS (http:/ / www.roseschool.it/ca_redivivus/) has shown. It is typical for the interwar time, when the use of reinforced concrete spread quickly in these countries, where Modernist architecture had begun to be widely accepted, but where the possibilities of the material had not yet been adequately researched. Greece has been a second case study for this paper, as the earthquake of Thessaloniki and typical seismic retrofit measures there were considered, and since the preliminary results of the typology of buildings in Athens suggest that our model buildings suit the typology there. Greece is also a country that suffers strong earthquakes. Future studies will compare the cost efficiency studies already carried out in this country. In Italy, the Novecento and Fascist/Rationalist buildings from the interwar period display a similar typology, [42] has continued the studies from CA'REDIVIVUS in this field. Another study from Italy based on multi-criteria decisions for earthquakes, extending the study to earthquake areas, is [43], which offers another way of connecting the research to case studies in Italy, besides those named in the introduction $[18,19]$.

An original concept of costs levels, depending on expected earthquake, was developed. The method does not depend on databases for the given site where it is to be applied, and the computation is realised only taking into account the usual hourly labour and material costs. In this way, it is easy to apply these methods to any other location that is rich in reinforced concrete buildings. The project management method is built on costs devices, and can be continued through simulations in construction management games.

A comparison of preventive retrofitting and post earthquake damage repairs shows the importance of planned conservation. If the retrofit measure is applied at the right time between successive earthquakes, or before the first earthquake, and in the right proportions, substantial savings are to be expected in repair costs. At the same time, the benefit for inhabitants, i.e., less disruption as a consequence of the damage caused by the earthquake, and the subsequent repair measures, can be prevented through timely retrofitting at the exterior, since damages affect also interior elements, as shown. The architectural heritage itself is protected through controlled preventive retrofitting, as compared to the repair of the most significant elements, which might suffer damage in the earthquake.

The costs have been put into the context of the decisions of experts, and larger participation in conservation efforts, of which retrofitting is one part. According to the newest tendencies to examine disaster management, social sciences and humanities have been involved, namely cultural heritage, economics, and the sociology of architecture, in defining the decision tree in benefit-costs analyses. There are the benefits, which determine which retrofit system and strategy should be used; these have to be balanced with the costs, according to multi-criteria decision. Making the transition from the tree to a taxonomy and ontology permits subsequent application in computer software.

As research has shown, the total costs of repair and retrofit are about $30 \%$ of the potential cost of rebuilding (see Table 3 for details), with few exceptions, when the earthquake which struck was relatively weak. The cost for repair, in contrast, vary from between 3 to 8 times more than the preventive retrofit; this is why cost curves were developed, in order to assign an optimal time when the retrofit measures have to be taken, between a weak and a strong earthquake. 
Acknowledgments: The first part of this research has been funded by a scholarship in frame of the Graduiertenkolleg "Naturkatastrophen" at the University of Karlsruhe, Germany. Research continued under postdoctoral funding supported by the strategic grant POSDRU/159/1.5/S/133391, Project "Doctoral and Post-doctoral programs of excellence for highly qualified human resources training for research in the field of Life sciences, Environment and Earth Science" co-financed by the European Social Found within the Sectorial Operational Program Human Resources Development 2007-2013.

Conflicts of Interest: The author declares no conflict of interest.

\section{References}

1. Federal Emergency Management Agency. Typical Costs for Seismic Rehabilitation of Existing Buildings; FEMA 156-157; Summary and Supporting Documentation; Federal Emergency Management Agency: Washington, DC, USA, 1988.

2. Neddermann, R. Kostenermittlung im Altbau: Aktuelle Baupreise-Rechtliche Grundlagen-Technische Beurteilung-Kostenermittlungsmethoden, 4th ed.; Werner: Neuwied, Germany, 2007.

3. Institutul de Cercetări în Construcții și Economia Construcților (INCERC). Probleme de Economia Construcţiilor; INCERC: Bucharest, Romania, 2000.

4. Federal Emergency Management Agency. NERPH Guidelines for the Seismic Rehabilitation of Buildings; FEMA 274; Board of State and Community Corrections(BSCC): Washington, DC, USA, 1997.

5. ATC-40 (Applied Technology Council). Seismic Evaluation and Retrofit of Concrete Buildings; California Seismic Safety Commission: Sacramento, CA, USA, 1996.

6. Smyth, A.W.; Altay, G.; Deodatis, G.; Erdik, M.; Franco, G.; Gülkan, P.; Kunreuther, H.; Lus, H.; Mete, E.; Seeber, N.; et al. Probabilistic Benefit-Cost Analysis for Earthquake Damage Mitigation: Evaluating Measures for Apartment Houses in Turkey. Earthq. Spectra 2004, 20, 171-203. [CrossRef]

7. Lekidis, V.A.; Karakostas, C.Z.; Sous, I.I.; Anastasiadis, A.; Kappos, A.; Panagopoulos, G. Evaluation of economic loss for structures in the area struck by the 7/9/1999 Athens earthquake and comparison with actual repair costs. Brebbia, C.A., Beskos, D.E., Manolis, G.D., Spyrakos, C.C., Eds. Earthq. Resist. Eng. Struct. V 2005, 81, 301-312.

8. Kappos, A.J.; Dimitrakopoulos, E.G. Feasibility of pre-earthquake strengthening of buildings based on cost-benefit and life-cycle cost analysis, with the aid of fragility curves. Nat. Hazards 2008, 45, 33-54. [CrossRef]

9. Kappos, A.J.; Stylianidis, K.C.; Pitilakis, K. Development of seismic risk scenarios based on a hybrid method of vulnerability assessment. Nat. Hazards 1998, 17, 177-192. [CrossRef]

10. Kappos, A.; Lekidis, V.; Panagopoulos, G.; Sous, I.; Theodulidis, N.; Karakostas, C.; Anastasiadis, T.; Salonikios, T.; Margaris, B. Analytical Estimation of Economic Loss for Buildings in the Area Struck by the 1999 Athens Earthquake and Comparison with Statistical Repair Costs. Earthq. Spectra 2007, 23, 333-355. [CrossRef]

11. Zikas, T.; Gebauer, F. Decision process and optimization rules for seismic retrofit programs. In Proceedings of the International Symposium on Strong Vrancea Earthquakes and Risk Mitigation, MATRIX ROM, Bucharest, Romania, 4-6 October 2007; pp. 472-484.

12. Zikas, T.; Engelmann, H.; Fiedrich, F. A concept for an open-source software project for earthquake risk management. In Proceedings of the 100th Anniversary Earthquake Conference-Managing Risk in Earthquake Country, San Francisco, CA, USA, 18-22 April 2006; Mira Digital Publishing: Chesterfield, MO, USA, 2006.

13. Bostenaru Dan, M. Calculation of costs for seismic rehabilitation of historical buildings. In Earthquake Resistant Engineering Structures III; Brebbia, C.A., Corz, A., Eds.; WIT Press: Southampton, UK, 2001; pp. 515-524.

14. Bostenaru Dan, M. A cost-effectiveness study of retrofitting and strengthening techniques for damaged buildings. In Earthquake Loss Estimation and Risk Reduction; Lungu, D., Wenzel, F., Mouroux, P., Tojo, I., Eds.; Independent Film: Bucharest, Romania, 2004; Volume 2, pp. 161-170.

15. Bostenaru Dan, M.; Gehbauer, F. Applicability and economic efficiency of seismic retrofit measures on historic buildings of mid-XXth century. In Proceedings of the 13th World Conference on Earthquake Engineering, Vancouver, BC, Canada, 1-6 August 2004.

16. Bostenaru Dan, M. Wirtschaftlichkeit und Umsetzbarkeit von Gebäudeverstärkungsmaßnahmen zur Erdbebenertüchtigung, 1st ed.; Shaker Verlag: Aachen, Germany, 2006. 
17. Bostenaru Dan, M. Economic impact of preventive retrofit in comparison with post-earthquake repair. In Conservare l'Architettura: Conservazione Programmata per il Patrimonio Architettonico del XX Secolo/Conserving Architecture: Planned Conservation of XXth Century Architectural Heritage; Electa: Milano, Italy, 2009; pp. 194-203.

18. Caterino, N.; Iervolino, I.; Occhiuzzi, A.; Manfredi, G.; Cosenza, E. Dissipazione passiva nella selezione dell'intervento di adeguamento sismico di un edificio in c.a. mediante analisi decisionale multicriterio. In Proceedings of the ANIDIS (Associazione Nazionale Italiana di Ingegneria Sismica) 2007, Pisa, Italy, 10-14 June 2007.

19. Caterino, N.; Iervolino, I.; Manfredi, G.; Cosenza, E. Comparative Analysis of Multi-Criteria Decision-Making Methods for Seismic Structural Retrofitting. Comput.-Aided Civ. Infrastruct. Eng. 2009, 24, 432-445. [CrossRef]

20. Bostenaru Dan, M.; Bourlotos, G. Calculation of costs for seismic retrofit of stone masonry buildings in Greece. In Proceedings of the Azores 1998-International Seminar on Seismic Risk and Rehabilitation of Stone Masonry Housing, Horta, Portugal, 9-13 July 2008.

21. Glaister, S.; Pinho, R. Development of a simplified deformation-based method for seismic vulnerability assessment. J. Earthq. Eng. 2003, 7, 107-140. [CrossRef]

22. Crowley, H.; Pinho, R.; Bommer, J.J. A probabilistic displacement-based vulnerability assessment procedure for earthquake loss estimation. Bull. Earthq. Eng. 2004, 2, 173-219. [CrossRef]

23. Borzi, B.; Pinho, R.; Crowley, H. Simplified pushover-based vulnerability analysis for large scale assessment of RC buildings. Eng. Struct. 2008, 30, 804-820. [CrossRef]

24. Bal, I.E.; Crowley, H.; Pinho, R. Displacement-based earthquake loss assessment for an earthquake scenario in 14Istanbul. J. Earthq. Eng. 2008, 12, 12-22. [CrossRef]

25. Nistor, S. Heritage at Risk 2002-2003. National Report for Romania, In CNR ICOMOS, Romania. Available online: http://www.international.icomos.org/risk/2002/romania2002.htm (accessed on 11 May 2018).

26. Malczewski, J. GIS and Multicriteria Decision Analysis; John Wiley \& Sons: New York, NY, USA, 1999.

27. Nägele, H. Die Restaurierung der Weißenhofsiedlung 1981-1987; Karl Krämer Verlag: Stuttgart, Germany, 1992.

28. Fingerhuth, K.; Koch, M. Gestaltung zwischen Entwurf und Vereinbarung. Zur Verständigung über Funktion und Ästhetik bei der Planung und Realisierung von Neubauten. In Planung und Kommunikation; Selle, K., Ed.; Bauverlag: Wiesbaden/Berlin, Germany, 1996; pp. 23-40.

29. Strassert, G. Das Abwägungsproblem bei Multicriteriellen Entscheidungen. Grundlagen und Lösungsansatz-unter Besonderer Berücksichtigung der Regionalplanung; Verlag Peter Lang: Frankfurt am Main, Germany, 1995.

30. Brzev, S.; Greene, M. (Eds.) World Housing Encyclopedia Summary Publication 2004; EERI Publication Number WHE-04; EERI Publication: Oakland, CA, USA, 2004.

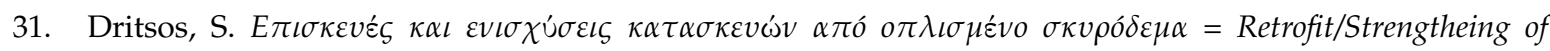
Reinforced Concrete Constructions; Translation Provided by Gregor Bourlotos; University of Patras: Patras, Greece, 2000.

32. Öztürk, G.; Bostenaru Dan, M. Comparative study of FRP seismic retrofit of existing URM infilled RC structures from a construction management point of view. Proceedings of FRPRCS, University of Patras, Patras, Greece, 16-18 July 2007.

33. Ponzo, F.C.; Di Cesare, A.; Arleo, G.; Totaro, P. Protezione sismica di edifici esistenti con controventi dissipativi di tipo isteretico: Aspetti progettuali ed esecutivi. Progettazione Sismica 2010, 2, $19-42$.

34. Grant, D.N.; Bommer, J.J.; Pinho, R.; Calvi, G.M.; Goretti, A.; Meroni, F. A Prioritization Scheme for Seismic Intervention in School Buildings in Italy. Earthq. Spectra 2007, 23, 291-314. [CrossRef]

35. Tobriner, S. Bracing for Disaster: Earthquake-Resistant Architecture and Engineering in San Francisco, 1838-1933, Heyday Books; University of California: Berkeley, CA, USA, 2006.

36. Charleson, A.; Preston, J.; Taylor, M. Architectural Expression of Seismic Strengthening. Earthq. Spectra 2001, 17, 417-426. [CrossRef]

37. Pinho, R. Assessment and Retrofitting of Reinforced Concrete Structures, Course Notes; European School for Advanced Studies in Reduction of Seismic Risk: Pavia, Italy, 2001.

38. Bostenaru Dan, M. Multi-criteria decision model for retrofitting existing buildings. Nat. Hazards Earth Syst. Sci. 2004, 4, 485-499. [CrossRef]

39. Penelis, G.G.; Penelis, G.G.; Paschalidis, K.P. The Structural Upgrading of the Army Pension Fund (A.P.F.) Building in Athens; FIB: Athens, Greece, 2003. 
40. Manos, G.C.; Papanaoum, E. Earthquake behaviour of a reinforced concrete building constructed in 1933 before and after its repair. Struct. Stud. Repairs Maint. Herit. Archit. XI 2009. [CrossRef]

41. Bosi, A.; Pegon, P. The ELSA Database and What Can Be Done Regarding SERIES Networking Activities; EUR 23931 EN; OPOCE: Luxembourg, Luxembourg, 2009.

42. Stefano, P.; Chiara, R. A Macroseismic Method for Vulnerability Assessment of Rationalist Architectural Heritage. Proc. Econ. Financ. 2014, 18, 173-180. [CrossRef]

43. De Lotto, R.; Gazzola, V.; Gossenberg, S.; Morelli di Popolo, C.; Venco, E.M. Proposal to Reduce Natural Risks: Analytic Network Process to Evaluate Efficiency of City Planning Strategies. In Computational Science and Its Applications-ICCSA 2016; Gervasi, O., Ed.; Lecture Notes in Computer Science; Springer: Cham, Switzerland, 2016; Volume 9789.

(C) 2018 by the author. Licensee MDPI, Basel, Switzerland. This article is an open access article distributed under the terms and conditions of the Creative Commons Attribution (CC BY) license (http:/ / creativecommons.org/licenses/by/4.0/). 